\title{
Catalysis in Multifunctional Reactors
}

\author{
Sanjay M. Mahajani ${ }^{1}$ and Basudeb Saha ${ }^{2}$ \\ ${ }^{1}$ Department of Chemical Engineering, Indian Institute of Technology, Bombay, Powai, Mumbai \\ 400 076, India \\ ${ }^{2}$ School of Engineering, London South Bank University, 103 Borough Road, London SE1 0AA, \\ UK
}

\section{Introduction}

Multifunctional reactor is broadly defined as a multifaceted reactor system that combines conventional reactor with any physical process to enhance the overall performance of the process that brings cost-effectiveness and/or compactness to a chemical plant. This multi-functionality can exist either on micro (catalyst) level or on macro (reactor) level [1]. There is substantial information available on several ways to achieve this task. Combining reaction with separation is one such popular approach wherein, separation when performed in-situ, brings several benefits like increase in per-pass conversion and/or selectivity, energy integration, longer catalyst life etc. When a separation process e.g. distillation, adsorption etc. is to be performed simultaneously with reaction, it imposes more restrictions on the reactor design so as to meet possible conflicting requirements coming from the reaction and the separation. Existence of multiple phases, problems associated with heat and momentum transfer, mixing issues etc. make the process complex thereby attracting attention of experts in reaction engineering, catalysis, modeling and simulation and process design.

Catalysts being an integral part of a reactor system, many efforts have been made to manipulate its design to meet the above mentioned challenges. Few examples are, inserting special catalyst-filled envelopes in distillation column to reduce pressure drop, manipulating hydrophobicity of ion exchange resin in reactive chromatography for selective separation, grafting the catalyst in membrane material etc. In this chapter, we review the recent literature on catalysts and their modified forms used in multifunctional reactors which combine reaction 
and separation. We restrict ourselves to four most studied reactors i.e. reactive distillation, reactive stripping, membrane reactor and chromatographic reactor.

\section{Reactive Distillation (RD)}

Reactive distillation is a multifunctional reactor in which chemical reaction and fractional distillation can be performed simultaneously. It is generally applied to a reversible reaction wherein, at least one of the products has a different volatility with respect to the other compounds. The most general configuration of reactive distillation unit consists of: (i) a rectification section in the upper zone; (ii) a reactive section in the middle; and (iii) a stripping section in the lower zone. Due to simultaneous operation of reaction and separation, this

process offers smaller plant size, lower operating costs, higher yields, and energy saving. The basic requirement for the success of reactive distillation is to achieve reasonable reaction rates in the temperature and pressure ranges that are governed by vapor-liquid equilibrium. It is particularly advantageous for equilibrium limited reactions wherein, the separation of at least one of the products as it is formed can drive the reaction to near completion. Reactive distillation allows the reaction to be carried out much closer to the stoichiometric ratio of the feed flows. Further, it is useful in the case of reactions in which a high concentration of the product or one of the reactants can cause undesired side reactions. Literature is replete with the information on various aspects of reactive distillation. Sharma and Mahajani [2] have reviewed various applications of reactive distillation. The important applications include etherification, dimerization, oligomerization, condensation, esterification, trans-esterification, hydrolysis of esters, hydration, hydro-desulfurization, alkylation, acetalisation, ketalization etc.

Successful commercialization of RD technology requires special attention to the hardware design which means, the standard designs used for conventional distillation may not work in the case of RD. The column should provide favorable conditions for both reaction and distillation. The catalyst used in RD columns (RDCs) can be either homogeneous or heterogeneous. The homogeneous catalysts generally offer high activity but separation of catalyst from product mixture incurs additional cost. However, heterogeneous catalyst such as, anion and cation exchangers, zeolites, etc. are preferred over their homogeneous counterparts. These catalysts 
offer various advantages that include elimination of separation and recycling of catalyst, elimination of acid disposal problems, exactly defined position of height of reaction zone in the column, less corrosion problems, lower investment cost and relatively easier operation. The challenge in heterogeneously catalyzed reactive distillation is to decide, how, where and which type of catalyst is to be placed in the reactor to get the desired performance. The location of the reaction zone inside the column depends on the type of reaction and the relative volatilities of the components. The column internals for reactive distillation should be designed in such a way that there is an efficient contact between solid catalyst and liquid phase, and one gets efficient separation by distillation with a high capacity and low pressure drop. A liquid hold-up higher than that is necessary for normal distillation columns, is required if the reaction is slow $[3,4]$. The optimal solution must be a compromise between these requirements. The mechanical arrangement of the catalyst inside the column and its shape are of primary importance, to achieve an optimal performance for both reaction and distillation. In the following section, RD column hardware for both homogeneous reactions and heterogeneous reactions are explained.

\subsection{Homogeneous catalysis}

RD columns in which a reaction takes place in the liquid phase, is operated counter-currently and sufficient degree of staging can be achieved in a multi-tray column or in a column with random or structured packing. The packing in this case is inert and serves only to provide even liquid distribution in the column and to suppress liquid phase back-mixing. To increase the productivity of RD column, it is important to maximize the liquid hold up in the column as the Hatta number is usually less than unity in most of the cases [5]. Packed columns usually have much lower hold-up than tray columns, so for homogeneous RD, tray columns are preferred. The tray column can be operated in the spray, mixed froth, or bubbly flow regimes. As higher liquid hold-up and higher residence time are desired, the preferred regime of operation is the bubbly flow regime, which can be achieved by operating the column at lower superficial vapor velocities. The higher weir height ensures higher liquid hold-up on the tray. The bubble cap trays provide higher liquid holdup, and reverse flow trays with additional sumps can be used to increase the liquid residence

time. Eastman Kodak uses specially designed tray for the manufacture of methyl acetate [6]. Computational fluid dynamics (CFD) can provide better insight into the flow pattern and hence 
the column performance based on liquid hold-up, pressure drop, residence time distribution and mass transfer aspects. It can predict whether there are internal circulation in the liquid flowing on the tray [7].

\subsection{Heterogeneous catalysis}

For heterogeneously catalyzed processes, hardware design poses considerable challenge. The catalyst size, hold-up in the column, low pressure drop, good vapor-liquid and liquid-solid contact and mass transfer are the basic criteria for design. The catalyst particle sizes used in such operations are usually in the range of 1-3 mm. Larger particles are not preferred because they lead to intra-particle diffusion limitations, whereas dumped packing of these small particles can create flooding problem. To overcome these limitations the catalyst particles are generally enveloped within wire gauze structure. A variety of envelope geometries has been developed for this purpose. An excellent review of various such structures that are used as column packings, is given by Taylor and Krishna [8]. Some of the important packing geometries are as follows: (i) porous spheres filled with catalyst inside them; (ii) cylindrical shaped envelopes with catalyst inside them; (iii) wire gauze envelopes with various shapes: spheres, tablets, doughnuts, etc.(Figures 1 (a)) [9]; (iv) horizontally disposed wire-mesh "gutters" filled with catalyst; (v) horizontally disposed wire-mesh tubes containing catalyst; (vi) catalyst particles enclosed in cloth wrapped in the form of bales; (vii) catalyst particles sandwiched between corrugated sheets of wire gauze [10]; (viii) catalyst coated on suitable supports;(ix) internally finned monoliths (Figure 1 (b)) [11]; (x) micro engineered catalysts (Figure 2) [12].

\section{Figure 1. Schematic of reactive distillation columns}

It is worth mentioning the efforts by the researchers from ABB Lummus to improve integration of catalyst and reactor engineering in case of reactive distillation [12]. The novel catalyst system termed as micro-engineered catalyst (MEC) allows one to maximize internal and external mass transfer while reducing the hydrodynamic limitations at the same time. MEC systems consist of web of very thin microfibers which enclose small $(<50 \mu)$ catalyst particles (See Figure 2 ). It can be either in the form of microencapsulation or thin coating. The metal sheet used here as a support has a very high porosity $(\sim 90 \%)$ and it can be made in the form of structure that is 
suitable for the required application i.e. column packing, in such a way that external mass transfer is also minimized.

\section{Figure 2. Micro-engineered catalyst concept [12]}

The important advantage of the structured catalyst sandwich structures is that the liquid follows a criss-crossing flow path which improves the radial dispersion. In addition to this, the frequent criss-crossing leads to significant improvement in mass transfer operation within the sandwich structures. The direct coating of normal distillation packings, as Raschig rings or Berl saddles, with a catalytic layer can also be used, but such a solution is probably feasible only for fast reactions, because of the limited catalytic surface area available for the reaction [8]. The important catalysts and structures are elaborated in the subsequent sections.

\subsubsection{Alternate reaction-distillation zones}

The column is provided with alternate spaces that offer different structures for reaction and distillation. In a reactive distillation column it is important that for the liquid phase reaction, the liquid comes in maximum possible contact with the solid catalyst. The main hurdle for this is the

presence of up-going vapor flow that causes a disturbance. In order to overcome this problem, the catalyst may be placed only in the down-comer of a conventional tray distillation column. However, this option is not attractive as it causes tremendous pressure drop. An alternate arrangement is shown in Figure 3. In the reaction zone, a separate channel is provided for the vapor flow, while the catalyst is fully surrounded by liquid. The distillation zone typically comprises of conventional non-reactive trays. Number of such separate reaction and distillation zones may be provided as per the requirement.

\section{Figure 3: Alternate regions for reaction and distillation in a column [13]}

\subsubsection{Emulsion or block polymerization}

In this category, the polymeric catalysts are either prepared by conventional emulsion polymerization or molded with a thermoplastic like polyethylene or it is prepared by block polymerization in molds. These catalytic packings may be given a desired shape and size. 
Moreover, the gas-liquid mass transfer area can be considerably improved. The widespread commercialization of these types of catalysts, especially the block polymers, has been probably impeded by the mechanical stresses developed because of the osmotic swelling. The advantage of these packings is that the catalytic activity can still be maintained closer to the original catalytic material [14].

\subsubsection{Tray columns}

The catalyst particles can be used in the suspended (fluidized) form over a distillation tray or catalyst envelopes can be placed on a tray or in the down comers in RD column along the direction of the liquid flow path across a tray. These envelopes are almost completely immersed in the froth on the tray, ensuring good contact between liquid and catalyst. The structure of such reactive distillation column is shown in Figure 4. There exist typically two zones viz. liquidsolid catalytic reaction zone and a vapor-liquid separation zone. Such an arrangement circumvents the need to specially manufacture catalytic packings and obviates the problems associated with shut-down of the operation to replace the spent catalyst. It may offer better mass and heat transfer characteristics due to the presence of fine catalyst particles. However, the process may suffer from high-pressure drop and operational problems like blockage of screen support by catalytic particles. Syntheses of cumene $[15,16]$, linear alkylbenzene $[17,18]$ and methyl acetate hydrolysis [19] have been successfully tested in such suspended catalytic distillation column.

The arrangements that can be used to place catalyst in the tray towers are as follows [8]:

(i) Place catalyst envelopes along the liquid flow path. Weirs provide a liquid level to cover the containers. In this way, only the liquid phase makes full contact with the catalyst, while moving across the tray, and the gas flows axially through the tray holes.

(ii) Place catalyst envelopes within the down comers. The primary drawback with this method is limited volume available for catalyst inventory.

(iii) Place the catalyst envelopes near the down-comer. In this case also the catalyst inventory is limited.

(iv) Alternate arrangement of mass transfer trays and packed catalyst sections. 


\section{Figure 4: Structure of suspended catalytic distillation column [19]}

\subsection{Catalysts used in reactive distillation}

The main challenges for $\mathrm{R} \& \mathrm{D}$ in heterogeneous catalysis in reactive distillation are to develop catalysts that are active under the operating conditions of distillation. Furthermore, these catalysts should have relatively long-life, so as to avoid excessive shutdowns, catalyst replacements, and start-ups that are more complex than in conventional operation.

\subsubsection{Ion exchange resins}

Among the various heterogeneous catalysts, ion exchange resin (IER) catalysts are the ones that are used the most. This is probably because majority of liquid phase reversible reactions, benefited by $\mathrm{RD}$, are acid catalyzed and they occur at relatively low temperatures. IERs are temperature sensitive and hence cannot be used in the case of reactions involving less volatile components. The ion exchange resins such as Amberlyst-15, Amberlite IR-120, Dowex 50W, Indion 130 etc. have been used as catalysts in several applications of reactive distillation [2,20]. Almost all the configurations discussed above have been investigated with IER as catalysts. Table 1 summarizes the important applications that are based on ion exchange resins as catalysts. The applications include dehydration, etherification, esterification, transesterification, hydrolysis, acetalization, aldol condensation etc.

\section{Table 1: Here}

The recent literature on the catalysts other than ion exchangers is also reviewed. Table 2 lists these catalysts and the corresponding reactions. A few examples are elaborated below.

\section{Table 2: Here}

\subsubsection{Zeolites}

Zeolites, because of their molecule sieving property, offer additional opportunities to achieve higher selectivity. Moreover, they stand relatively high temperature. A recently studied example 
is conversion of phenyl-ethanol to styrene (Eq. 1) for which, reactive distillation with highly active catalyst helps surpass equilibrium and achieve higher conversion of phenyl-ethanol. However, the selectivity towards styrene is the main concern. Medium-pore zeolite H-ZSM-11, showed high styrene yields than the large pore zeolites H-Beta [53]. This is because dehydration is favored in micro pores that are large enough to accommodate reactants but small enough to inhibit side reactions. It is concluded that the zeolites having pore size of around $5.5 \mathrm{~A}^{\circ}$ can accommodate mono aromatics and reject large molecules such as polyromatics. Hence, these catalysts in $\mathrm{RD}$, offer not only higher conversion but also higher yield of styrene. Other parameters of importance are $\mathrm{Si} / \mathrm{Al}$ ratio and crystal size. Interestingly, crystal size increases with increase in $\mathrm{Si} / \mathrm{Al}$ ratio, because Al-rich gels are known to form small crystals than Al-lean gels. Styrene yield decreases with increase in crystal size and $\mathrm{Si} / \mathrm{Al}$ ratio. However, the performance of large pore zeolites is independent of crystal size. Hence, catalyst pore size and crystal size are the important parameters that influence the overall performance of this process.

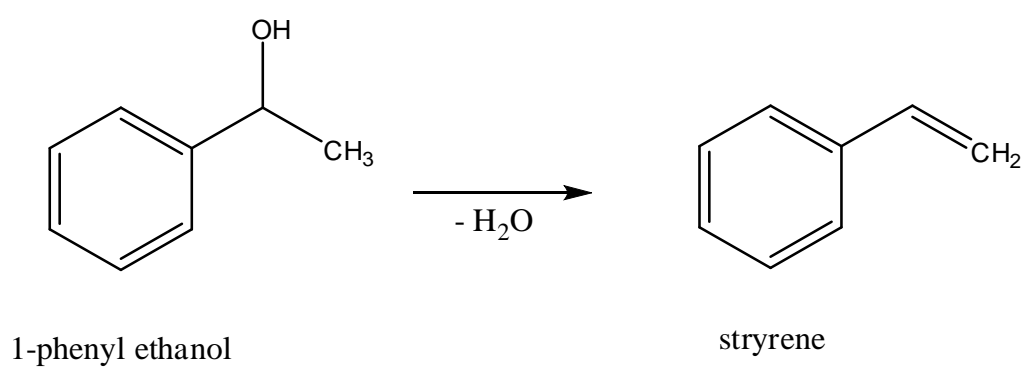

\subsubsection{Enzyme catalysts}

Another interesting case is the use of bio catalysts (e.g. enzymes) in RD. Enzyme can be used in RD column in two ways; lipase CALB immobilized on a silica-gel matrix and in the form of granule. Trans-esterification of ethyl butyrate with $n$-butanol (Eq. 2) in a reactive distillation mode has been studied in the presence of these catalysts [54]. Simultaneous removal of ethanol helped in achieving higher conversions (up to 98\%) beyond equilibrium. It has also been proved that leaching of catalyst is minimum. Thermal stability of biocatalyst is the main factor that would decide their potential for commercialization. 


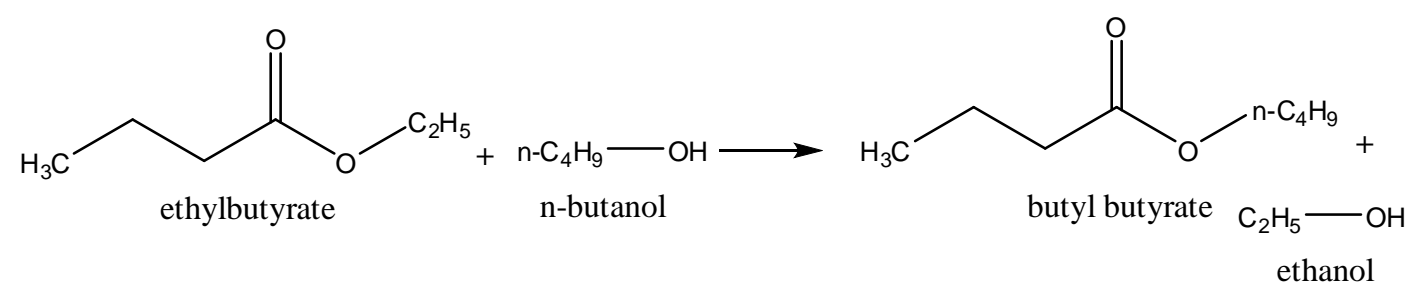

\subsubsection{Ionic liquids}

Ionic liquids have higher thermal stability and they stand temperatures as high as $593 \mathrm{~K}$. Because of their low volatility, separation is easier and these catalysts, in spite of being in liquid form, can be conveniently used and would prove to be cost-effective. In reactive distillation, activity of different acidic imidazolium (ionic liquids) catalysts has been tested for trans-esterification of 2butyl acetate (SBAC) with methanol (Eq. 3) [55]. It is found that 1-(3-sulfopropyl)-3methylimidazolium hydrogen sulfate $\left[\mathrm{HSO}_{3}-\mathrm{PMIM}\right] \mathrm{HSO}_{4}$ has much higher activity than other catalysts such as $[\mathrm{BMIM}] \mathrm{HSO}_{4},\left[\mathrm{HSO}_{3}-\mathrm{BMIM}^{-} \mathrm{HSO}_{4},\left[\mathrm{HSO}_{3}\right.\right.$-PMIM $]$ p-TSA and $\left[\mathrm{HSO}_{3}-\right.$ $\mathrm{PMIM}] \mathrm{CH}_{3} \mathrm{SO}_{3}$. This is mainly because the acidity value is higher than all the other catalysts. The performance of the catalyst has been tested in RD column and a conversion up to $97 \%$ is realized.

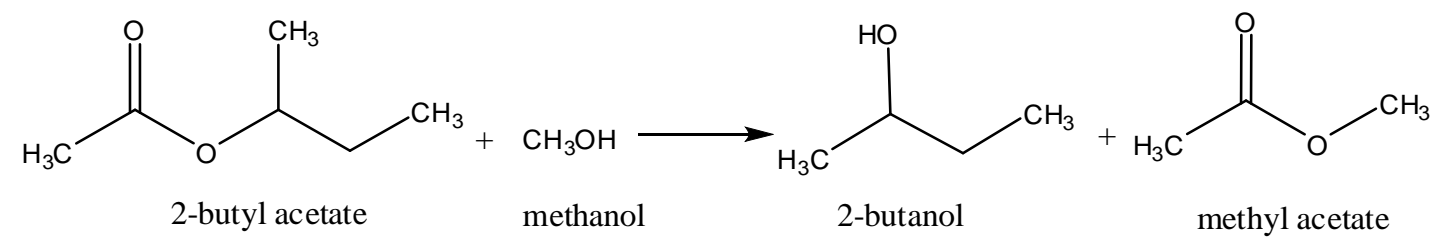

\subsubsection{Desulfurization of gasoline}

Desulfurization process of gasoline mainly consists of acid catalyzed alkylation of thiophenic sulfur followed by product separator. Desulfurization happens via olefinic reaction to form alkylated thiophenes (Eq. 4a) which have higher boiling point than sulfur components. Hence, the separation of sulfur compounds becomes easier using distillation. The reaction is also accompanied by undesired oligomerization as a side reaction (Eq. 4b). By adjusting operating conditions in RD column, one can reduce olefin oligomerization, which helps increase the selectivity for the alkylated product [56]. The catalysts used in this reactor include: zeolites ( $\mathrm{Na} \beta$ 
[57], HY [58-60], HMCM-22 [59,61], MCM-41 [62,63], HBEA [59]), sulfonic resins (NKC-9 [56,64,65], Amberlyst-35 [65-67]), solid phosphoric acid [65], silica-supported $\mathrm{H}_{3} \mathrm{PW}_{12} \mathrm{O}_{40}$ $6 \mathrm{H}_{2} \mathrm{O}$ (HPW) [68], HPW on $\gamma$-Fe2O3 [69], HPW supported on $\mathrm{MgF}_{2}$ [70] etc. Interestingly, reactive distillation can replace the two-step process with a single unit that combines reaction and distillative separation [56]. RD experiments were mostly performed using ion exchange resins such as NKC-9 [56,64] and Amberlyst-35 [66,67]. Among all the operating and design parameters, reactive stage location is the sensitive parameter that decides the performance of desulfurization in a RD column [66].

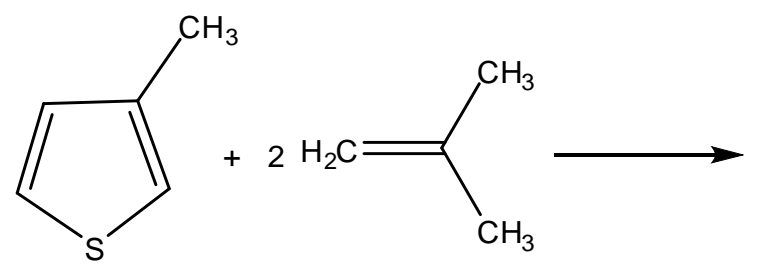

3-methylthiophene isobutylene

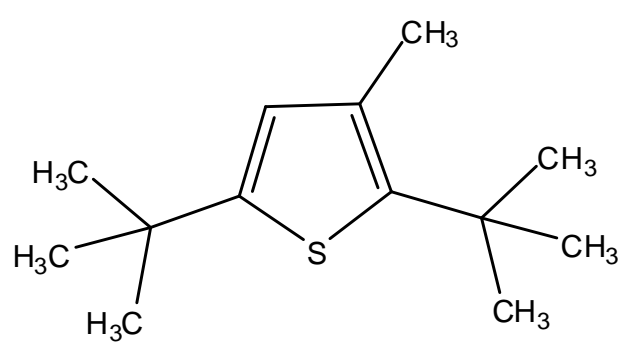

2
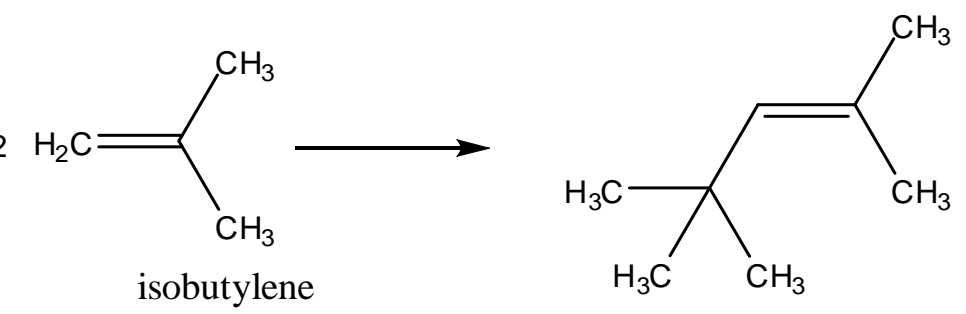

In addition to acid catalyzed reactions, there is a large range of other reactions such as hydrogenation, chlorinations etc., which can benefit by RD configuration [2].

\subsubsection{Epoxidation of alkenes/terpenes}

Epoxides are valuable building blocks for organic synthesis, particularly for the production of commercially important products for pharmaceuticals, plastics, fragrances, food additives, paints and adhesives [71,72]The conventional methods for the industrial production of epoxides employ either stoichiometric peracids or chlorohydrin as an oxygen source [73,74]. However, both methods have a serious environmental impact, as the former produces an equivalent amount of acid waste, whilst the later yields chlorinated by-products and calcium chloride waste. In addition, there are safety issues associated with the handling and storage of peracids [75]. Hence, there is a strong need for cleaner catalytic epoxidation methods that use safer oxidants and 
produce little waste. The new route includes developing a greener epoxidation process by utilizing a heterogeneous catalyst and a benign oxidant, such as tert-butyl hydroperoxide (TBHP), as it is environmentally benign, safer to handle and possesses good solubility in polar solvents $[73,76]$.

A number of authors reported a novel and greener solvent-free process for alkene epoxidation using environmentally benign tert-butyl hydroperoxide (TBHP) as an oxidant $[74,75,76,77,78]$. In this process, polybenzimidazole supported molybdenum complex (PBI.Mo) and a polystyrene 2-(aminomethyl) pyridine-supported molybdenum complex (Ps.AMP.Mo) were used as catalysts for the epoxidation of alkenes/terpenes. During the epoxidation reaction, tert-butanol is also formed as a co-product, and hence, this is termed as an atom-efficient process. Furthermore, tertbutanol can be efficiently recycled through hydrogenolysis and oxidation [79]. Recently, continuous epoxidation of alkenes and terpenes (e.g. cyclohexene, 1-octene, limonene, $\alpha$-pinene, etc.) with TBHP using PBI.Mo and Ps.AMP.Mo catalysts have been successfully conducted in an RDC [80,81]. The remarkable catalytic performance of this catalyst has been confirmed in continuous epoxidations of cyclohexene, limonene and $\alpha$-pinene employing TBHP as the oxidant [80,81]. Very high conversion of TBHP to cyclohexene oxide (>98\%) and $100 \%$ selectivity towards cyclohexene epoxide was achieved during epoxidation of cyclohexene in the RDC. This study confirmed that the energy efficiency of this process is about 4-6 fold that of conventional processes.

\section{Reactive Stripping}

Reactor stripping (RS) is a multifunctional reactor in which reaction and separation are carried out in a single piece of equipment just like $\mathrm{RD}$, however, it offers greater freedom in the choice of temperature and pressure conditions than RD [88]. RS is particularly advantageous for applications wherein, the reactants and products are temperature sensitive and the common window for reaction and separation using RD does not exists as some of the reactants get destroyed or degraded in side reactions if heated up to boiling temperatures. For example, condensation of phenol and acetone to produce bisphenol-A, wherein, boiling points of majority of components, except acetone, are relatively high [89]. RS can be operated in concurrent or 
counter current or mixed mode type of operation depending on the application of interest. One of the products is stripped off simultaneously from the reacting liquid phase, either using the reactant gas stream itself or by means of an inert gas stream to overcome the reaction equilibrium limitations.

There are various applications reported in literature for which RS is more efficient than its more popular counterpart i.e. RD. Few important applications are Knoevenagel condensation of aldehydes or ketones, esterification of fatty acids, etc. [90]. Some of the reported applications of reactive stripping and the catalyst used are summarized in Table 3. The catalyst required for given applications plays an important role in design and performance of the RS process. In general, all the possible catalyst bed configurations that can be used for packed bed type reactive distillation system can also be applied for reactive stripping with major better hydrodynamic parameters such as low column hold-up and pressure drop, higher catalytic activity and long catalyst life.

\section{Table 3: Here}

Recently, monolithic catalytic packing are also being investigated widely for RS. Conventionally monolith catalysts have been developed for gas-solid systems and used extensively for exhaust gas cleaning, in automobiles, and removal of VOCs and NOx, considering their large geometrical surface area, relatively low cost, low pressure drop, and efficient catalyst utilization. For application in reactive stripping, these monolithic catalyst supports are being modified to accommodate two phase flow by introducing bigger size internal channels with or without fines to provide better gas-liquid interfacial area as well as less irrigated bed pressure drop. These catalysts have been studied extensively for esterification of carboxylic acids with alcohols. In industry, these reactions are catalyzed by using solid-acid catalyst such as zeolites and ion exchange resins in slurry form [96]. The monolithic support coated with solid-acid catalyst or ion exchange resin catalyst provides an attractive process alternative as it does not involve separation of catalyst after completion of reaction. Furthermore, the packed column reactor configuration also enables introduction of inert gas flow for stripping of water from the reaction zone to shift the equilibrium of the reaction to 
achieve better yield and selectivity [97]. Flow patterns in a reactor and also the gas-liquid mass transfer are very important factors. A few important applications of reactive stripping are explained in the following sections.

\subsubsection{Esterification}

Esterification, like in RD, has also been investigated in RS mode. RS is applicable especially when either alcohol or the acid is less volatile and conducting the reaction, in RD mode, is not advisable. Beers et al. [97] found that the rate esterification of 1-octanol with hexanoic acid (Eq. 5a) increased by $15-20$ times in the presence of catalyst such as zeolite BEA ( $\mathrm{Si} / \mathrm{AL}=37.5$ ) or Nafion/silica composite with 13\% (SAC 13). Complete conversion was achieved with both the catalysts but the selectivity towards ester is highest with SAC13 catalyst. It may be due to the formation of ethers in the side reaction (Eq. 5b) over the strongly acidic catalytic sites. This confirms the selection of catalyst and operating conditions are very important to achieve conversion and also selectivity of the required product.

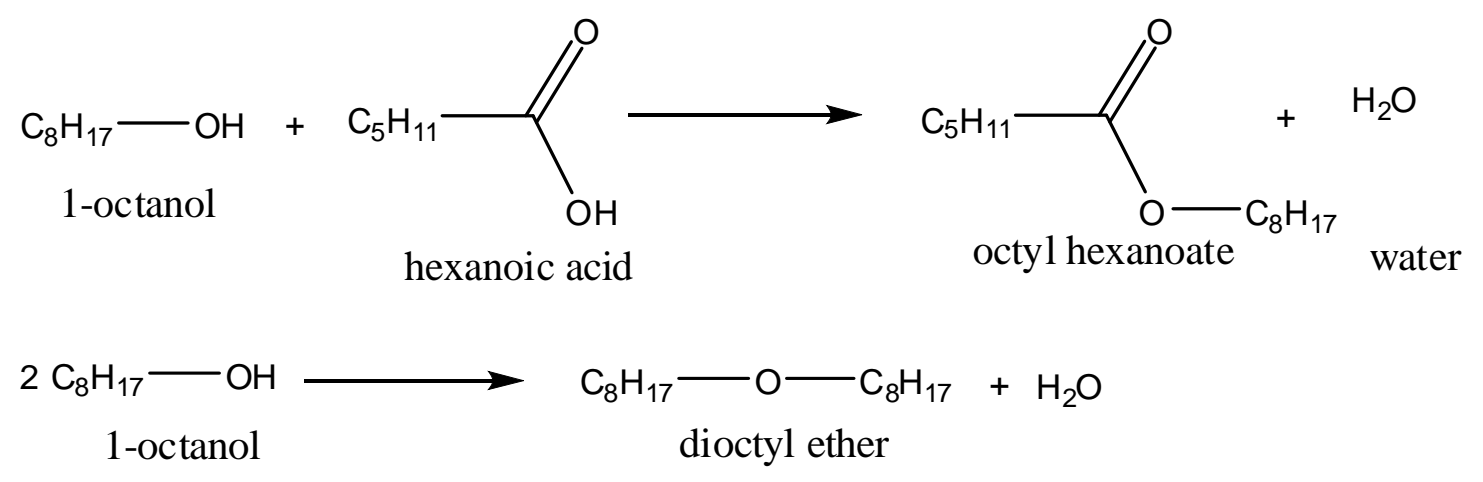

\subsubsection{Aqueous phase reforming (APR) of sorbitol}

Hydrogen may be produced by aqueous phase reforming of sorbitol in the presence of $\mathrm{Pt}$ catalysts (Eq. 6). Higher hydrogen concentration in the reactor favors the reverse reaction as well as the side reactions which consume hydrogen. An in-situ stripping of hydrogen thus enhances conversion and also the selectivity. An excellent mass transfer attributes offered by micro reactors implies overall reaction to be kinetically controlled [91,92]. This demands highly active catalyst to enhance the production rate. A bimetallic catalyst (Pt-Ru) offers higher conversion but reduced the selectivity for hydrogen, ultimately implying neutral effect in terms of production. However, continuous hydrogen stripping increases the conversion and also gives nearly same 
hydrogen selectivity thereby resulting in higher hydrogen production rate. This is a good example of synergism between catalyst design and reactor configuration leading to an enhanced performance ( 0.2 to 6.6 moles of $\mathrm{H}_{2} / \mathrm{moles}$ of metal $/ \mathrm{min}$ ).

$$
\mathrm{C}_{n} \mathrm{H}_{2 m} \mathrm{O}_{n}+n \mathrm{H}_{2} \mathrm{O}=n \mathrm{CO}_{2}+(m+n) \mathrm{H}_{2}
$$

\subsubsection{Dehydration of xylose to furfural}

Stripping of water during the course of reaction for dehydration of xylose (Eq. 7) produces higher yield of furfural. The activity of catalysts like $\mathrm{Nb}_{2} \mathrm{O}_{5}$ and Amberlyst-70 for the formation of furfural, in RS mode, has been studied in past [94,95]. It is concluded that Lewis acidic sites help in conversion of xylose and strong Brønsted sites are responsible for higher furfural yield. To maximize the conversion and yield, a hydroxylated $\mathrm{MgF}_{2}$ catalyst is used for which, one can tune Lewis/ Brønsted acid sites ratio. This helps in achieving higher conversion and higher yield of furfural.

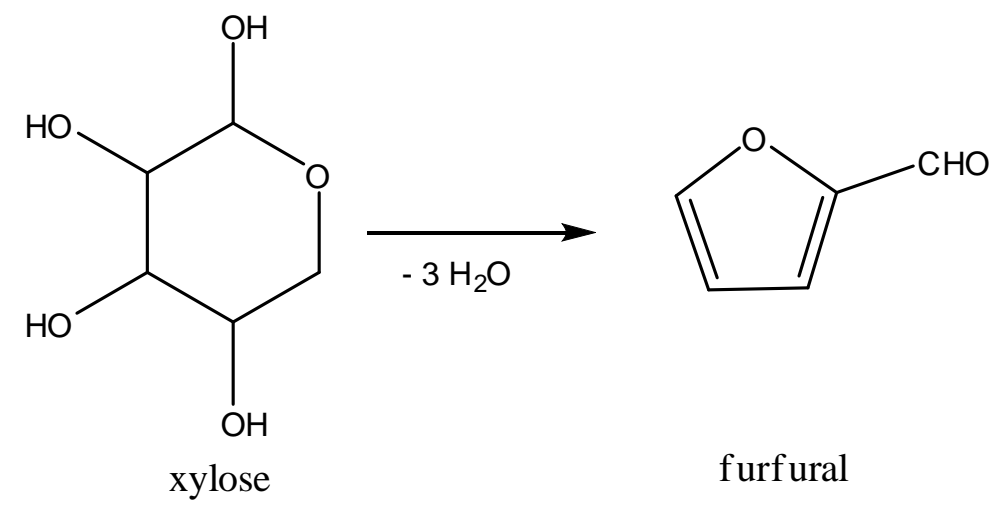

\subsubsection{Catalytic exchange of hydrogen isotopes}

An interesting case of process intensification involving equilibrium reaction and separation is catalytic hydrogen-water isotope exchange process used for separation of hydrogen isotopes. In this process the catalytic isotope exchange reaction takes place in the vapor phase over a wetproofed solid catalyst between the stripped-off component and the gas. The isotope exchange reaction is carried out in a trickle bed reactor (TBR) filled with a wet-proofed catalyst in which hydrogen and liquid water are contacted in countercurrent mode over the catalyst bed to transfer 
heavier isotope of hydrogen i.e. deuterium from liquid water to hydrogen through exchange reaction that takes place in the gas phase [99]. The overall process may be written as,

$$
H D O(L)+H_{2}(g)=H D(g)+H_{2} O(L)
$$

Conventionally, noble metal catalyst such as platinum supported on high surface area supports such as alumina, silica or activated carbon are found to be most effective for the exchange reaction. However, these catalysts were found to be catalytically active only in gas phase as they lose their catalytic activity as and when they come in contact with liquid water due to wetting of the catalyst surface, preventing reactants from reaching the active sites. Hence, a Pt catalyst on carbon is blended with PTFE (platinum-carbon-PTFE (0.001:0.009:0.99 w/w) to render hydrophobicity thereby providing direct exposure of catalytic sites to the reacting gas phase [93]. On the other hand, because of poor wetting, the gas-liquid mass transfer necessary to strip HDO off from the liquid phase is adversely affected. To circumvent this problem, a mixture of wetproof catalyst and ceramic Raschig rings was used in a trickle bed reactor as shown in Figure 5. An enrichment from $30 \mathrm{ppm}$ deuterium to $200 \mathrm{ppm}$ deuterium was achieved a single pass. The interplay between reaction rate and mass transfer rate leads to an optimum proportion of catalytic and non-catalytic packings in the column. It is also reported that the catalyst used in this study imposes severe pore diffusion resistances implying internal effectiveness factor to be not more than 0.2 , which provides further scope for improvement in the catalyst design.

\section{Figure 5: Schematic of hydrogen isotopic exchange process [93]}

\section{Catalytic Membrane Reactors}

Catalytic membrane reactors (CMRs) combine reaction with membrane separation. In a catalytic membrane reactor, the selective removal of a reaction product through the membrane or a controlled addition of reactant through the membrane helps in shifting the equilibrium. In addition to this, these reactors are also useful in enhancing the selectivity of catalytic reactions [102]. Based on their material of construction, the membranes used for CMR applications can be classified into two categories: organic and inorganic. Organic membranes have good separation 
properties as compared to inorganic membranes. However, the drawback of organic membranes is that generally, they do not withstand temperatures above $473 \mathrm{~K}$, which limits their use in catalytic processes. Inorganic membranes are preferred for severe process conditions and high temperature applications.

Various arrangements have been proposed to combine a catalyst and a membrane in a catalytic membrane reactor (CMR). They are mainly classified into three categories as shown in Figure 6. In the first case, the membrane is permeable only to products while retaining reactants and catalyst (Figure 6 (a)). Another type of application is the one in which membrane acts as a contactor between two reactants (Figure 6(b)). In the third category, one of the products or reactants is permeable through membrane (Figure 6(c)). In the latter case, this property of membrane can be used to meet several objectives i.e. conversion or selectivity enhancement through product withdrawal (Figure 6(d)) and selectivity enhancement through optimum reactant dosing (Figure 6(e)) etc.

\section{Figure 6: Catalytic membrane reactors [103]}

Few important applications of membrane reactors and the concerned details are given in Table 4. In the following section, we review some selected applications wherein, catalyst in membrane reactors plays an important role.

\section{Table 4: Here}

\subsection{Biodiesel production}

CMR offers unique way to remove the large molecules of oil which cannot pass through the membrane pores. On the other hand, the produced biodiesel, which is essentially a mixture of fatty acid alkyl esters with relatively small molecular sizes, is able to pass through the membrane along with alcohol, glycerol and the catalyst. The equilibrium of the trans-esterification reaction (Eq. 9) is thus shifted to the product side. Several catalysts have been used for the production of biodiesel in membrane reactor which include, $\mathrm{KOH}$ supported on activated carbon [104], $p$-TSA 
supported on MCM-41 [105], Mg-Al hydrotalcites [106] etc. Biodiesel has also been produced using poly vinyl alcohol (PVA) membranes with solid base catalysts for the trans-esterification of soybean oil with methanol. The membranes were prepared by dispersing hydrotalcite in the polymer solution. The hydrophobicity of membrane may be increased by adding succinic anhydride in PVA. It is observed that by increasing the hydrophobicity of the PVA membranes, its catalytic activity increases at the cost of FAME yield.

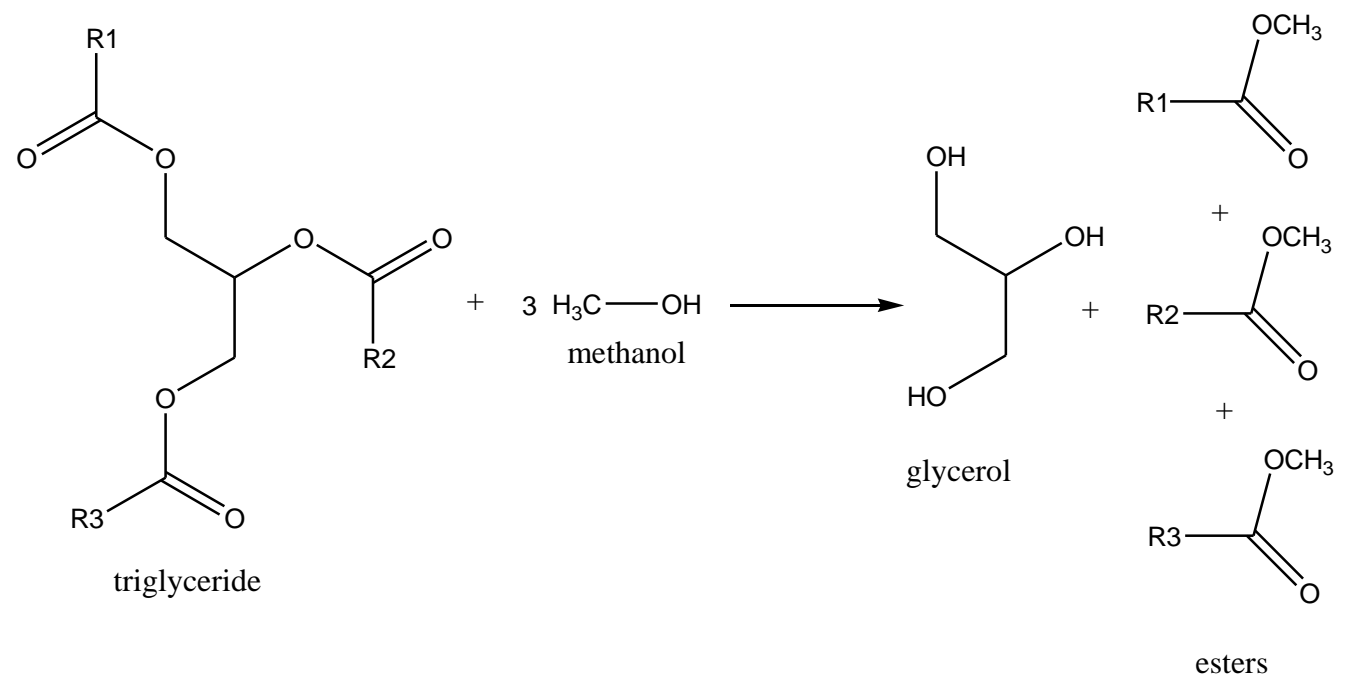

\subsection{Dehydrogenation}

The increasing demand for propene and its derivatives requires further development of available technologies giving higher efficiency and improved propene selectivity. It can be produced by dehydrogenation of alkane (Eq. 10) using catalytic membrane reactor. A conventional way of dehydrogenation of propane is to use a tubular flow reactor combined with a gas-separation membrane [107]. Reaction may be performed at high temperatures (773-873 K) using $\mathrm{Cr}_{2} \mathrm{O}_{3} / \mathrm{Al}_{2} \mathrm{O}_{3}$ catalyst and gas-separation membrane (silica/alumina). Hydrogen formed during the reaction can be separated through the membrane to overcome the equilibrium limitation. A maximum $36 \%$ conversion of propane at $773 \mathrm{~K}$, which is double the equilibrium value, has been reported. In another study, a hollow fiber membrane reactor (HFMR-I) using Pt (0.5 wt.\%)/y$\mathrm{Al}_{2} \mathrm{O}_{3}$ catalyst was developed for dehydrogenation of propane to propene [120]. It is further improved to a highly compact multifunctional $\mathrm{Pd} /$ alumina hollow fibre membrane reactor (HFMR-II) that consists of a thin and defect-free Pd membrane coated directly onto the outer 
surface of an alumina hollow fibre substrate. It has a unique asymmetric pore structure, i.e. a sponge-like outer layer and a finger-like inner layer where $\mathrm{Pt}(1 \mathrm{wt} . \%) / \mathrm{SBA}-15$ catalyst is deposited. SBA-15 offers high catalyst loading and high surface area for Pt as compared to $\gamma$ alumina. With hollow fibre membrane reactor (HFMR) propene selectivity and space-time yield is 10 times higher than that obtained in a conventional fixed bed reactor.

$$
\mathrm{C}_{3} \mathrm{H}_{8} \rightarrow \mathrm{C}_{3} \mathrm{H}_{6}+\mathrm{H}_{2}
$$

In another example, styrene is produced by catalytic dehydrogenation of ethylbenzene. This reaction is also accompanied by side reactions giving benzene and toluene (Eq. 11). Membrane reactor helps increase the conversion of ethylbenzene and improve selectivity. There are various membranes that were successfully applied for this reaction, for example, ceramic membranes [121], zeolite membranes [122], palladium membranes[123,124] etc. In all the studies, significant increase in conversion and selectivity were observed by using membrane reactor when compared to fixed bed reactor. For example, She et al. [123] found increase in conversion up to $10 \%$ and increase in selectivity up to $15 \%$ using palladium supported on porous stainless steel tubes.

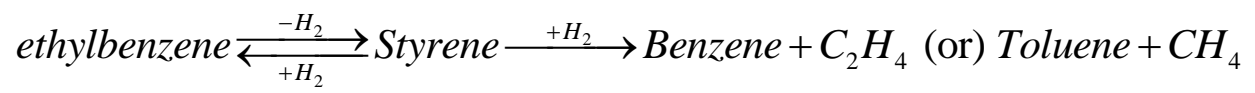

\subsection{Oxidative coupling of methane (OCM)}

Catalytic membrane reactor is a promising way of coupling of methane to $\mathrm{C}_{2+}$ or formation of ethane+ethylene from methane (Eq. 12). CMR has major advantage in term of selectivity of $\mathrm{C}_{2+}$ product as compared to co-feed packed bed reactor. The experimental results clearly demonstrated that it was beneficial to distribute the feed of oxygen along the reactor length for methane oxidative coupling reactions [110]. Out of many inorganic membranes, ionic-electronic conducting membrane [109], porous $\gamma$-alumina membrane [61], catalytic perovskite hollow fibre membrane [125] are the few membranes which showed higher activity for the OCM reaction.

$$
\mathrm{CH}_{4} \stackrel{+\mathrm{O}_{2}}{\longrightarrow} \mathrm{C}_{2} \mathrm{H}_{2}, \mathrm{C}_{2} \mathrm{H}_{4}, \mathrm{C}_{2} \mathrm{H}_{6}+\mathrm{H}_{2} \mathrm{O}
$$

The outer surface of CMR consists of a mixed ionic-electronic conducting membrane (MIECM) $\mathrm{Ba}_{0.5} \mathrm{Ce}_{0.4} \mathrm{Gd}_{0.1} \mathrm{Co}_{0.8} \mathrm{Fe}_{0.2} \mathrm{O}_{3-\delta}$ (BCGCF) coated using sol-gel method and the inner surface of the 
membrane tube was coated with $\mathrm{Na}-\mathrm{W}-\mathrm{Mn} / \mathrm{SiO}_{2}$ catalyst [109]. This CMR performed best in terms of $\mathrm{C}_{2+}$ yield of $34.2 \%$ with methane conversion of $51.6 \%$ and $\mathrm{C}_{2+}$ selectivity of $67.4 \%$ which is higher than a conventional reactor. OCM experiments were also conducted in a porous $\gamma$-alumina membrane reactor using $\mathrm{Mn}-\mathrm{W}-\mathrm{Na} / \mathrm{SiO}_{2}$ catalyst [110]. A maximum $27.5 \% \mathrm{C}_{2+}$ yield was obtained at optimum reaction condition. It was observed that higher helium flow rate gave higher C2 selectivity and yield, whereas changing methane flow rate did not significantly affect the reactor performance. Dense $\mathrm{La}_{0.6} \mathrm{Sr}_{0.4} \mathrm{Co}_{0.2} \mathrm{Fe}_{0.8} \mathrm{O} 3$ (LSCF) hollow fibre membrane was used for OCM reaction, a maximum $21 \%$ yield of $\mathrm{C}_{2+}$ was obtained using $\mathrm{SrTi}_{0.9} \mathrm{Li}_{0.1} \mathrm{O}_{3}$ catalyst [125], although it is still lower than the $30 \%$ threshold for commercial feasibility.

\subsection{Partial oxidation of methane to synthesis gas}

Partial oxidation of methane (POM) (Eq. 13) has attracted growing attention for the production of synthesis gas from methane with a ratio of $\mathrm{H}_{2} / \mathrm{CO}$ equal to two, which is a suitable feedstock for the synthesis of hydrocarbons or methanol and the subsequent production of liquid fuels. Catalytic membrane reactor allows us to separate oxygen and catalytic POM process in a single step. There are many types of catalytic membrane reactors used for PMO process, few important CMRs are dual-phase composite membrane reactor [111], Ceramic membrane reactor [112] and $\mathrm{Ru}$ deposited ceramic membrane reactor [113]. The catalytic partial oxidation of methane to syngas over perovskite $\mathrm{SrTiO}_{3}$, was studied with $\mathrm{Ce}_{0.8} \mathrm{Sm}_{0.2} \mathrm{O}_{2-\delta}-\mathrm{La}_{0.8} \mathrm{Sr}_{0.2} \mathrm{CrO}_{3-\delta}$ dual-phase composite membrane reactor [111]. Approximately $74 \% \mathrm{CO}$ and $75 \% \mathrm{H}_{2}$ selectivity at $17 \% \mathrm{CH}_{4}$ conversion can be achieved under the optimum operating conditions at $950^{\circ} \mathrm{C}$ and $\mathrm{CH}_{4}$ feed rate of $20 \mathrm{ml} \mathrm{min}$. The catalytic POM for the synthesis of syngas was also performed using a twozone fixed bed of a Ni/ $\mathrm{Al}_{2} \mathrm{O}_{3}$ catalyst inside a modified ceramic membrane [112]. A maximum $96.4 \%$ conversion of methane (more than equilibrium conversion, 94\%) was achieved at $1073 \mathrm{~K}$ and at atmospheric pressure and $\mathrm{CH}_{4}, \mathrm{O}_{2}$ and $\mathrm{N}_{2}$ feed ratio of 2/1/1. A catalytic ruthenium membrane reactor (CRMR) has also been investigated [113]. Two layers of Ru nanoparticle were coated over ceramic reactor giving maximum methanol conversion over $59 \%$ with $\mathrm{H}_{2}$ selectivity over $71 \%$ at $773 \mathrm{~K}$ and feed ratio of $\mathrm{CH}_{4} / \mathrm{O}_{2} / \mathrm{N}_{2}=2 / 1 / 14$ (total feed rate $=381.5 \mathrm{~mL} / \mathrm{min}$ ).

$$
\mathrm{CH}_{4}+\frac{1}{2} \mathrm{O}_{2} \longrightarrow \mathrm{CO}+2 \mathrm{H}_{2}
$$




\section{Chromatographic Reactor}

Chromatographic reactor is one of the multi-functional reactors wherein reaction and separation could be carried out in a single vessel or equipment. The concept of chromatographic reactor lies in the adsorptivity of the different species involved rather than differences in their volatility as in the case of reactive distillation (RD). Chromatographic reactor is particularly advantageous to use, as an alternative to RD, when the difference in the volatility of the species are small or the components are non-volatile or sensitive to temperature. Ideally, a chromatographic reactor employs a mixture of solid catalyst and an adsorbent. Nowadays, it is common to use a solid catalyst that also acts as an adsorbent. This section will explain the concept, types and applications of liquid chromatographic reactors.

\subsection{Concept of a Chromatographic Reactor}

The basic concept of chromatographic reactor can be easily understood by studying a single chromatographic column, operated in the conventional batch mode. Consider an equilibrium limited reaction in a single chromatographic column given by reaction (Eq. 14):

$$
\mathrm{A} \Leftrightarrow \mathrm{C}+\mathrm{D}
$$

where, $\mathrm{D}$ is the most strongly adsorbed on the catalyst while $\mathrm{A}$ and $\mathrm{C}$ are less adsorbed on the catalyst. Reaction (Eq. 14) takes place under diluted conditions in an inert solvent. Consider a pulse of $\mathrm{A}$ being injected into a fixed bed comprising an adsorbent of high affinity towards $\mathrm{D}$, and lower one towards $\mathrm{A}$ and $\mathrm{C}$. As the reaction takes place, both product species migrate through the reactor at different velocities, with D being retained more strongly than $\mathrm{A}$ and $\mathrm{C}$, and thus staying behind the reactive front. This continuous separation of the two products leads to a suppression of the backward reaction, thus driving the conversion towards completion and enabling the withdrawal of two high-purity product fractions at the column outlet. It is worth mentioning the following things - (i) in a chromatographic reactor separation of the two products can only be achieved if complete conversion has been achieved; (ii) it is not necessary to have a reactant of intermediate affinity towards the stationary phase as long as $\mathrm{C}$ and $\mathrm{D}$ can be separated. 
The extension of the above concept to bimolecular reactions is straightforward. However, it must be noted that in a bimolecular reactions one has to avoid the separation of the reactants by choosing a suitable stationary phase and solvent. This can easily be achieved in applications by using one of the reactants as solvent in order to ensure its availability at the reaction locus $[126,127]$. There are several classes of reactions to which reactive chromatography can be applied. Probably, the widest one is given by esterification reactions, catalysed, for example, by acidic ion exchange resins [126,128] as here the obvious polarity difference between the two products (i.e. ester and water) make their separation easy on different adsorbents, for example ion exchange resins which acts both as a catalyst and an adsorbent.

In general, the packing of a chromatographic reactor column is carried out with two different solid particles one being the catalyst and other is the adsorbent [129]. Amberlyst-15, a cation exchange resin catalyst which acts both as the catalyst for the reaction and adsorbent for the chromatographic reactor was used to carry out the reactions in chromatographic reactors [126128,130-138]. Similarly, Amberlyst-31 [127], DOWEX 50W-X8 [139,140] and TS-1[141] have been used in the chromatographic reactor experiments for their dual characteristics of both catalyst and adsorbent. The industrial application of chromatographic separation is in the field of chiral and bioseparations [142]. Chromatographic reactors can be operated in both batch and continuous modes.

\subsection{Types of Chromatographic Reactor}

A chromatographic reactor mainly consists of a stationary phase and a mobile phase. It can be operated in either batch (discontinuous) mode or continuous mode i.e., the reactant or the reactant mixture are fed continuously or discontinuously to the chromatographic reactor. The stationary phase acts both as an adsorbent and a catalyst. As a result, the reaction and the separation take place simultaneously inside the chromatographic reactor. The common stationary phases are solids typically in the form of porous media with large specific surface areas. The solid phases can be individual adsorbent for self-catalytic or homogeneous catalysed reactions, adsorbent activated by metal ions or functional groups or a mixture of catalyst and adsorbent. The stationary phase may be a liquid coated on a solid support or a liquid retained by centrifugal 
force [143]. Based on the employed phases and the working principles, chromatographic reactor can be classified as explained in the following section.

\subsubsection{Batch Chromatographic Reactor (BCR)}

Batch chromatographic reactor (BCR) consists of a fixed volume packed with catalyst and/or adsorbent. For most of BCR experiments, the catalyst also acts as an adsorbent. In BCR, the adsorption is followed by the catalytic reaction after which the unreacted feed along with the products are eluted from the chromatographic reactor one after the other depending on the affinity towards the adsorbent [139]. Figure 7 shows the schematic of a batch chromatographic reactor (BCR) experimental set-up. Consider the reactions (Eqs. 14 and 15):

$\mathrm{A} \Leftrightarrow \mathrm{C}+\mathrm{D}$

$$
\mathrm{A}+\mathrm{B} \Leftrightarrow \mathrm{C}+\mathrm{D}
$$

Two kinds of experiments are carried out in a batch chromatographic reactor for each of the above two reactions mentioned. One is the reaction step and other is the regeneration step. During the reaction step, a known amount of reactant mixture, [A or $A+B$, depend on the reaction (Eq. 15) or (Eq. 16)] is continuously fed to the column which is initially saturated with a desorbent [B, in case of the reaction (Eq. 16) and inert solvent in case of the reaction (Eq. 15)]. As soon as the reactants enter the column, $\mathrm{A}$ or $\mathrm{A}+\mathrm{B}$ reacts in presence of the catalyst to produce C and D. D, which has a higher affinity towards resin gets readily adsorbed on the resin while C, with lesser affinity soon gets desorbed. As a result, $\mathrm{C}$ gets separated with $\mathrm{D}$, moves towards the exit of the column along with $\mathrm{A}$ and $\mathrm{B}$. Since $\mathrm{C}$ is separated from the reaction, the reaction proceeds until consumption of the limiting reactant (A).

\section{Figure 7 Schematic of a batch chromatographic reactor (BCR) experimental set-up}

With any specific location in the column, this process continues until the resin catalyst becomes saturated with A, C and D. When the resin catalyst becomes saturated, chemical equilibrium is 
achieved and the composition at every point in the column remains the same. At this point, the reaction step is stopped and the regeneration step is started. Pure B or inert solvent [depend on the reaction (Eq. 15) or (Eq. 16)] is continuously fed to the column for the regeneration by removing $\mathrm{A}, \mathrm{C}$ and $\mathrm{D}$ which are present in the column. When the composition of the exit of the column becomes same as the composition of the inlet $\mathrm{B}$, the regeneration step is considered to be complete. In recent works [144,145,146a,146b], acetic acid (A) is used as a reactant, $n$-hexanol (B) is used as a solvent (desorbent), $n$-hexyl acetate (C) and water (D) are the products.

For bimolecular reactions, separation of the reactants should be avoided by choosing a suitable stationary phase and solvent, as well as proper operating conditions [128]. This can be easily achieved by using one of the reactants as the solvent in order to ensure its availability at the reaction locus [127]. The major disadvantages of batch chromatographic reactors are low yields due to poor utilisation of stationary phase, high dilution of products due to high desorbent required and discontinuous operation. Comparison of batch chromatographic reactor and plug flow reactor (PFR) was reported by Falk and Seidal-Morgenstern [139]. The comparison of these reactors showed that the conversion of both reactors seems to be similar at the same dilution ratio, but the fixed-bed chromatographic reactor (FBCR) is more attractive for products separation without assistance of a downstream separator.

\subsubsection{True Counter-Current Chromatographic Reactor (TCR)}

Figure 8 shows the schematic of a true counter-current chromatographic reactor (TCR). Consider the reaction (Eq. 17):

$$
\mathrm{A}+\mathrm{B} \Leftrightarrow \mathrm{C}+\mathrm{D}
$$

where, component $\mathrm{D}$ is strongly adsorbed onto the adsorbent/catalyst followed by components A and $\mathrm{B}$, while $\mathrm{C}$ is the least adsorbed component. In TCR, the direction of the fluid flow is opposite to the direction of the true solid flow. The TCR is divided into four different sections. Each section performs specific function so that complete conversion and separation could be achieved. Section I is located between the desorbent (eluent) and the extract port. The flow rate 
is higher in this section compared to other sections. The higher flow rate is necessary to remove strongly adsorbed component (D) from the adsorbent/catalyst so that regeneration of the chromatographic reactor column is carried out. In Section II, between the extract and the feed port, components $\mathrm{C}$ and $\mathrm{D}$ are formed. For complete conversion of $\mathrm{A}$ and separation of products (i.e. $\mathrm{C}$ and $\mathrm{D}$ ), flow rate of this section should be adjusted such that $\mathrm{C}$ gets desorbed from the solid phase before reaching the extract port while D remains adsorbed in the solid phase which leads to a higher purity of D at the extract port. Section III is located between the feed and raffinate ports. The reaction takes place in this section and hence, this section is also referred to as the reactive section. Like section II, flow rate in this section is adjusted such that reaction time should be sufficient and the component D could get adsorbed on the solid phase. Thus, the fluid collected at the raffinate port has a very high concentration of the least adsorbed component (C). Section IV is placed between the raffinate and the desorbed ports. Before the fluid is recycled, it is cleaned in section IV. Component (C) is adsorbed from the fluid phase and transported back to section III along with the solid phase so that desorbent (B) is purified before being recycled to section I. True counter-current chromatographic reactor (TCR) suffers from practical problems with handling the solid phase as well as its requirement to achieve large rate of solid movement. Also, the abrasion between the solid particles and back mixing are difficult to avoid. Hence, a simplified version of TCR, i.e. continuous chromatographic reactor (CCR) also known as simulated moving bed reactor (SMBR) is more popular and considered to be a better option and is explained in the following section.

\section{Figure 8 Concept of a true counter-current chromatographic reactor (TCR)}

\subsubsection{Continuous Counter-Current Chromatographic Reactor (CCR)}

Continuous counter-current chromatographic reactor (CCR) is also referred to as simulated moving bed reactor (SMBR). The CCR was first developed by UOP (Universal Oil Products) in 1960 for the non-reactive separation of mixed xylenes [147]. This process was licensed as the SORBEX process. Figure 9 shows the schematic of a continuous counter-current chromatographic reactor (CCR) experimental set-up. It consists of several batch chromatographic reactor (BCR) columns packed with adsorbent/catalyst connected in series. The 
inlet and outlet ports of the reactants and products are switched at regular intervals. The time period between the successive switches of ports is called switching time $\left(t_{s}\right)$. Consider the reaction (Eq. 18):

$\mathrm{A}+\mathrm{B} \Leftrightarrow \mathrm{C}+\mathrm{D}$

where, component $\mathrm{D}$ is strongly adsorbed onto the adsorbent/catalyst followed by components A and $\mathrm{B}$, while $\mathrm{C}$ is the least adsorbed component. There are two inlet fluid streams [feed (A, B) and eluent (B)] and two outlet fluid streams [raffinate $(\mathrm{C}, \mathrm{B})$ and extract $(\mathrm{D}, \mathrm{B})$ ] as shown in Figure 9. These two inlet and outlet fluid port divides the unit into four sections (i.e., I, II, III and IV). Each section of CCR is replaced with several subsection packed with catalyst/adsorbent and each section performs specific job so that complete conversion and separation could be achieved. Component B acts both as feed reactants along with $\mathrm{A}$ as well as desorbent. For complete separation of products, component $\mathrm{C}$ should be least adsorbed and component $\mathrm{D}$ should be strongly adsorbed. The outlet ports are switched in the direction of fluid flow by one bed volume length. The working principle of CCR remains the same as TCR except that there is no movement of the solid phase in the CCR.

\section{Figure 9 Schematic of a continuous counter-current chromatographic reactor (CCR)}

Depending on the reactive system different CCR configuration set-up can be found in the literature. If the least adsorbed product (component $\mathrm{C}$ ) does not get adsorbed, the recycling of the pure desorbent is not possible; and section IV can be eliminated [127]. Also, if the regeneration of the adsorbent requires a change in the operating conditions i.e. temperature, pressure or change in desorbent then it would be more convenient to remove section I and perform the regeneration of the solid phase separately [148]. It may be noted that the adsorbent and catalyst materials used for CCR may be same, different or a mixture of the two. A comparison of CCR and TCR processes which have been discussed in detail by Lode et al. [149]can be summarised as follows - (i) TCR does not really apply to CCR units with finite number of columns per section, i.e. CCR tends to behave like TCR only for infinite columns in each section of infinite lengths; (ii) the two reactors (TCR and CCR) exhibit different residence time distributions and 
lead to different degrees of conversion, and (iii) TCR reaches true steady state while the CCR only reaches cyclic steady state.

\subsubsection{Centrifugal Partition Chromatographic Reactor (CPCR)}

Centrifugal partition chromatographic reactor (CPCR) is an integration of reaction and centrifugal partition chromatographic separation where counter-current distribution of species takes place in the absence of an adsorbent or catalyst. In this chromatographic reactor, two immiscible liquid phases with different densities are separated. The stationary phase with higher density is retained in the column by a combination of centrifugal force and geometric channel, while the mobile phase pass through the column as micro-droplets. A schematic of a centrifugal partition chromatographic reactor (CPCR) column is shown in Figure 10. A mixture of components A and B is separated due to their different affinities towards the two-liquid phases. The advantage of this chromatographic reactor is the large capacity of stationary phase compared to the conventional technique with liquid on solid support (i.e. liquid-liquid extraction). CPCR has been successfully applied for enzymatic reactions [150,151].

\section{Figure 10 Schematic of a centrifugal partition chromatographic reactor (CPCR)}

\subsubsection{Continuous Rotation Annulus Chromatographic Reactor (CRACR)}

In a continuous rotation annulus chromatographic reactor (CRACR), the stationary phase is packed into the annulus of two concentric cylinders, rotating continuously about the common axis. The mobile phase (eluent) is fed uniformly over the whole cross-section at the top of the annular space while the reactant is fed to a fixed feed inlet port. The reacting species are conveyed along the longitudinal axis of the annular space due to mobile phase flow, whereas they have a circumferential displacement by adsorption, desorption and rotational movement of annular. Hence, the components are separated and eluted from the reactor in different angles, compared to the fixed feed port. A schematic of a continuous rotation annular chromatographic reactor (CRACR) [152] is shown in Figure 11. The performance of a continuous rotation annular 
chromatographic reactor (CRACR) is similar to that of a batch chromatographic reactor (BCR) system except that the operation is carried out in continuous mode in CRACR [153]. The continuous operation of CRACR results in an inefficient utilisation of the solid phase and high desorbent consumption because complete separation is achieved without recycling of mixed fractions.

Figure 11 Schematic of a continuous rotation annular chromatographic reactor (CRACR)

\subsubsection{Reversed Flow Chromatographic Reactor (RFCR)}

The concept of a reversed flow chromatographic reactor is similar to that of an adsorptive reactor which is used for heat accumulation for regeneration, but it is related to mass accumulation [143]. The reverse-flow chromatographic reactor (RFCR) is a fixed-bed reactor packed with suitable adsorbent/catalyst. One of the reactant is fed at the middle of the reactor and the flow direction of the carrier is periodically switched. A schematic of a reversed flow chromatographic reactor (RFCR) is shown in Figure 12. If the reactants are strongly adsorbed onto the adsorbent/catalyst whilst products are least adsorbed onto the adsorbent/catalyst, the periodic switching of the carrier could lead to trap the strongly adsorbed reactant within the reactor. Two three way valves are controlled to keep the concentration profile of the reactant propagated in both the directions, but not out of the column. It was first applied by Agar and Ruppel [154] for the reduction of $\mathrm{NOx}$ with $\mathrm{NH}_{3}$, where only $\mathrm{NH}_{3}$ is adsorbed and the reactant is fed at the middle of the reactor. Recently, RFCR has been reviewed and it has shown that it can significantly improve conversion and yield for equilibrium or selectivity limited reactions [155-157]. Very little or no experimental information is available for this case [143].

Figure 12 Schematic of a reversed flow chromatographic reactor (RFCR) 


\subsection{Applications of Liquid Chromatographic Reactor}

There are several applications of liquid chromatographic reactor which are explained in detail in the following sections:

\subsubsection{Esterification Reaction}

\subsubsection{Triacetine Synthesis (Esterification of acetic acid with glycerol)}

Triacetine (glycerol triacetate) is used as plasticisers including filters in cigarettes and hence it is required to be of food grade quality. Gelosa et al. [134] studied the synthesis of triacetine which is a series of three steps esterification of glycerol with acetic acid in the presence of an acidic polymeric resin (Amberlyst-15) in a chromatographic reactor. Water molecule formed in each step of esterification along with monoacetine in first step, diacetine in the second step and finally triacetine in the third step of esterification.

The kinetics of esterification was studied in a batch reactor with and without Amberlyst-15. Gelosa et al. [134] reported that the conversion of non-catalysed esterification reaction was lower than $10 \%$ in one hour as compared to catalysed esterification, which had already attained equilibrium within that time. It was further reported that the effect of interphase mass transport resistances on the kinetics of triacetine synthesis was negligible by carrying out experiments using different stirrer speeds which gave similar results. However, it was also reported that intraphase mass-transport resistances may affect the kinetics of the process by conducting a nonreactive experiment where a small amount of water was added to the batch reactor containing only resin and glycerol at $333 \mathrm{~K}$. They also studied multi-component adsorption equilibria for three binary mixtures (i.e., water-acetic acid, water-glycerol and acetic acid-triacetine) and reported that water has a higher affinity for the resin due to the strong polarity that was made inside the resin by the sulfonic acid groups, followed by glycerol, acetic acid, monoacetine, diacetine and then triacetine. The effect of various parameters such as the reaction temperature, feed molar ratio of the reactants (acetic acid to glycerol) and catalyst to reactant ratio (resin to 
glycerol) was studied for the modelling of the chromatographic reactor. They concluded that there was a good agreement between the experimental findings and predicted values.

One important concern was addressed by Gelosa et al. [134] regarding the regeneration of the resin. Since acetic acid was used as a desorbent to remove a high degree of water from the column in the regeneration step, it has to be separated before recycling it back into the column which is an expensive operation. Otherwise, the water left in the resin after the regeneration step (largely because of recycling dilute acetic acid) may react in the breakthrough experiments with the purified triacetine to produce diacetine which could affect the process efficiency. This will affect the performance of the chromatographic reactor where a good separation between triacetine and diacetine is achieved when a well regenerated column was used. Therefore, the usage of either a dry acetic acid or desulfonated resins (lesser affinity towards water) was purposed by Gelosa et al. [134].

Gelosa et al. [134] carried out esterification of glycerol with acetic acid in the presence of Amberlyst-15 in a chromatographic reactor to address the concern of the column regeneration mentioned above with a possible solution. For these experiments instead of pure acetic acid, a reactive adsorbent (i.e. a mixture of acetic acid and acetic anhydride) were used as desorbent. Acetic anhydride reacts with water to produce acetic acid (the desorbent itself) in the regeneration step which resulted in the enhancement of process efficiency and reduction in the desorbent requirements.

\subsubsection{Methyl Acetate Synthesis (Esterification of acetic acid with methanol)}

Yu et al. [133], carried out synthesis of methyl acetate in a chromatographic reactor in the

presence of Amberlyst-15. Both reactive and non-reactive experiments were performed in a chromatographic reactor. Adsorption parameters were calculated from non-reactive experiments while kinetic parameters were obtained from reactive experiments. Methanol was used as a carrier solvent. A mixture of methyl acetate and water dissolved in methanol were used as a feed for the non-reactive breakthrough experiments, while a binary mixture of acetic acid and water 
were used as a feed for a reactive breakthrough experiments. Experiments were carried out at different temperatures, feed concentrations and flow rates. The samples were taken from the column outlet at regular intervals and were analysed. Methanol was used for the regeneration of the resin. Quasi-homogeneous $(\mathrm{QH})$ kinetic model was developed assuming that the reaction in the polymer phase to be homogeneous because of the presence of large volume of methanol in the reaction mixture. It was observed that methyl acetate has less affinity towards the resin than water and that the calculated adsorption constants of water and methyl acetate decreased with an increase in the temperature (since adsorption is an exothermic process). The model predicted the experimentally measured breakthrough curves very well. However, for a non-reactive breakthrough curves, the model was able to predict the experimental results for methyl acetate very well but not for water. The reason reported was that the tailing effect may be responsible for this and use of non-linear adsorption isotherm was purposed. Yu et al. [133] carried out synthesis of methyl acetate in the presence of Amberlyst-15 in a simulated moving-bed reactor (SMBR). Four jacketed steel columns in series were used and each column was connected to four rotary valves actuated by the control system. Methanol was

used as a mobile phase. The effect of different switching times, feed and desorbent flow rates were studied in detail and observation respective to various parameters were reported.

\subsubsection{3 $n$-Hexyl Acetate Synthesis (Esterification of acetic acid with $\boldsymbol{n}$-hexanol)}

Synthesis of $n$-hexyl acetate by esterification of acetic acid with $n$-hexanol using a gelular ion-

exchange resin catalyst (Purolite ${ }^{\circledR}$ CT-124) was studied in batch and continuous chromatographic reactors [144,145,146a,146b]. Batch chromatographic reactor column (BCRC) experiments were carried out using different parameters such as feed flow rate, feed mole ratio of $n$-hexanol to acetic acid, desorbent ( $n$-hexanol) flow rate and reaction step time to maximize the formation of $n$-hexyl acetate as well as to achieve complete conversion of acetic acid.

It was found that an increase in reaction step time increases unreacted acetic acid whereas an increase in feed molar ratio of $n$-hexanol to acetic acid decreases unreacted acetic acid at BCRC outlet. It was also observed that an increase in temperature increases desorption rate of the 
product ( $n$-hexyl acetate) so that it reaches BCRC outlet quicker. Also, an increase in feed flow rate was found to decrease the residence time of acetic acid to convert to $n$-hexyl acetate. Complete conversion (100\%) of acetic acid was achieved in the BCRC at a reaction temperature of $353 \mathrm{~K}$, feed molar ratio ( $n$-hexanol:acetic acid) of 3:1, feed flow rate of $0.2 \mathrm{~mL} / \mathrm{min}$, and reaction and regeneration steps time of $75 \mathrm{~min}$ each, respectively. The outlet fluid from the BCRC can be collected as products from both the reaction and the regeneration step experiments for the above-mentioned optimized parameters. The variable flow rate of $n$-hexanol in the regeneration step experiment was found to be the best way to minimize the solvent used in the BCRC. A continuous chromatographic reactor column (CCRC) was designed and constructed on the basis of BCRC experimental results. Since the CRC used for BCRC was fully packed with ion exchange resin, the bed volume is actually the volume of the CRC used, and hence, the bed volume was used as a scale up for the design of CCRC. An experiment with the optimized parameters with three $\mathrm{CRCs}$ for the reaction step experiment and one $\mathrm{CRC}$ for the regeneration step experiment was used for the synthesis of $n$-hexyl acetate in CCRC. The experiments carried out in a CCRC correlate very well with the results obtained from the optimized reaction condition in a BCRC for maximum formation of $n$-hexyl acetate and complete conversion of acetic acid.

\subsubsection{4 $\beta$-Phenethyl Acetate Synthesis (Esterification of acetic acid with $\beta$-Phenethyl alcohol)}

Synthesis of $\beta$-phenethyl acetate by esterification of acetic acid and $\beta$-phenethyl alcohol was investigated by Kawase et al. [128] in a simulated moving-bed reactor (SMBR). Amberlyst-15 catalyst was packed in eight stainless steel columns (in series) for this purpose. Each column had five solenoid valves to which desorbent, feed, extract, raffinate and effluent lines were connected. 1,4-Dioxane was used as a desorbent. It was reported that overall conversion in the range of $100 \%$ was achieved by the application of simulated moving-bed reactor if the following criteria was satisfied — the products should be separated out chromatographically and the reaction rate should be fast enough so that the reactant does not elute from the column outlet. 


\subsubsection{Methyl Acrylate Synthesis (Esterification of acrylic acid with methanol)}

Acrylic esters are monomers that are widely used for the production of coatings, adhesives, plastics etc. A conventional acrylic ester production involves several distillation columns (a reactor column, a water removal column, an azeotropic column and a column to separate the desired product from the undesired or by-products). In addition, an inhibitor has to be used in the whole process to minimise polymerisation of acrylic acid acrylic ester and to avoid its local depletion Moreover, reduced pressures are employed in the distillation columns to reduce the boiling temperatures. Besides polymerisation and fouling, one of the major problems of this process is the thermodynamic limitation due to the reaction equilibrium. Due to the drawbacks of the current production process, an increasing interest can be seen to develop alternative production technologies. The option to employ a heterogeneous catalyst, e.g. an ion exchange resin, makes the use of integrated reactor-separator processes like reactive distillation or reactive chromatography feasible. Since the former process would have similar drawbacks as the conventional one, i.e., fouling and polymerisation due to elevated temperatures, the latter could be a viable option since the separation is accomplished by selective adsorption in the liquid phase.

For the above reason, esterification of acrylic acid with methanol for the production of methyl acrylate in the presence of Amberlyst-15 in a chromatographic reactor was carried out by Strohlein et al. [136]. A jacketed batch column was filled with Amberlyst-15 in the hydrogen form immersed in methanol. The composition of the column outlet was analysed by gas chromatography. Methanol was used for the regeneration of the column. The batch column property was characterised by determining the total column porosity using tracer experiments. The effect of various parameters such as feed compositions, flow direction and flow rates have been studied for modelling the chromatographic reactor. A heterogeneous kinetic model, lumped kinetics and a linear driving force transport model have been developed. A more dispersed breakthrough and a sharp desorption profile was seen for the top-down flow and vice-versa for the bottom-up flow as observed by Strohlein et al. [136]. Also it was found that water adsorbs more strongly than the other components. 


\subsubsection{Hydrolysis Reaction}

Hydrolysis of four esters (i.e. methyl formate, methyl acetate, ethyl formate and ethyl acetate) was carried out in a chromatographic reactor with Dowex 50W-X8 catalyst [158]. An HPLC column was used for carrying out the experiments. Water was used as the mobile phase. Various parameters such as temperature, flow rate, feed concentration and injection volume were varied. Following observations were reported by Mai et al. [158] - (i) hydrolysis reaction of methyl formate and ethyl formate was faster as compared to methyl acetate and ethyl acetate; (ii) even at low flow rate, methyl acetate and ethyl acetate eluted from the column again confirming that these were the slowest reaction compared to methyl formate and ethyl formate; (iii) the peaks width was reduced considerably as the temperature was increased and in contrast, there was no major effect of temperature on the retention times in the studied range i.e. $298-328 \mathrm{~K}$, and (iv) the heterogeneous rate constant decreases in the order of methyl formate, ethyl formate, methyl acetate and ethyl acetate.

Similarly, heterogeneously catalysed hydrolysis reaction of methyl formate and methyl acetate in the presence of Dowex 50W-X8 was studied by Vu et al. [159]. It was reported that for the reaction, $2 \mathrm{~A} \Leftrightarrow \mathrm{B}+\mathrm{C}$, complete conversion and separation were only possible if reactant $\mathrm{A}$ has an intermediate adsorptivity. On the other hand, for the reactions, $A \Leftrightarrow B+C$, complete conversion and separation were possible for any order of adsorptivities.

Falk and Seidel-Morgenstern, [160] also carried out hydrolysis of methyl formate in the presence of Dowex 50W-X8 in a chromatographic reactor. The effect of temperature, residence time, feed, concentration and cycle time on the performance of the reactor was evaluated. Pseudohomogeneous $(\mathrm{PH})$ model was able to predict the experimental data over a wide range of parameters. Yu et al. [133] carried out hydrolysis of methyl acetate in a chromatographic reactor in the presence of Amberlyst-15. Both reactive and non-reactive experiments were performed in a chromatographic reactor. Adsorption parameters were calculated from non-reactive experiments while kinetic parameters were obtained from reactive experiments. Water was used as a carrier solvent. A mixture of methanol (or acetic acid) dissolved in water was used as a feed for the non-reactive breakthrough experiments, while a mixture of acetic acid and methanol 
dissolved in water or a binary mixture of methyl acetate and water was used as a feed for a reactive breakthrough experiments. Experiments were carried out at different temperatures, feed concentrations and flow rates. The samples were taken from the column outlet at regular intervals and were analysed. Water was used for the regeneration of the resin. Quasihomogeneous $(\mathrm{QH})$ kinetic model was developed assuming the reaction in the polymer phase is homogeneous because of the presence of large volume of water in the reaction mixture. The model predicted the experimentally measured breakthrough curves very well. It was reported that the reaction equilibrium constant of the hydrolysis of methyl acetate increased with an increase in the temperature as the backward reaction is an endothermic reaction.

\subsubsection{Hydroxylation}

Hydroquinone (HQ) and catechol (CT) are used in photographic processing and polymerisation inhibitors. Both HQ and CT can be produced by hydroxylation of phenol along with benzoquinone (BQ). Rangsunvigit and Kulrathipanja, [141] studied phenol hydroxylation in the presence of TS-1 catalyst (structure similar to silicalite) in a chromatographic reactor for the production of HQ and CT. Stainless steel columns were used and the samples from the column outlet were collected in a fraction collector, which was analysed by an HPLC. Unreacted $\mathrm{H}_{2} \mathrm{O}_{2}$ was analysed by a $\mathrm{H}_{2} \mathrm{O}_{2}$ kit. Aqueous mixture of $\mathrm{H}_{2} \mathrm{O}_{2}$ or water was used as a desorbent. It was reported that TS-1 could be easily regenerated by using pure water. Rangsunvigit and Kulrathipanja [141] also reported that the separation of each product can be achieved with water as desorbent depending upon the amount of phenol in the feed and that the selectivity of CT on TS-1 was found to be concentration dependent. Table 5 shows the summary of some of the applications of chromatographic reactors.

\section{Table 5: Here}




\section{Summary}

There has been considerable progress in the development of catalysts or catalytic systems used in multifunctional reactors. A special consideration needs to be given to their design to meet requirement from the point of view of both catalysis and reactor engineering. The associated effects on reactor level such as heat/mass transfer effects, pressure drop and mixing become crucial in many cases. The literature on catalysis in reactive distillation is dominated by ion exchange resins catalysts. However, new catalysts such as ionic liquid, biocatalyst, zeolites micro-engineered systems have also been tested successfully in laboratory and/or on pilot scales. Computational tools such as CFD are being used effectively to meet the above mentioned objectives. Wetting characteristics may be modified conveniently to meet the separation requirement as explained the case of reactive stripping for isotope exchange. Membrane reactors offer unique opportunities from the point of view of clever catalyst design and its integration into the membrane structure thereby bringing compactness to the unit. Chromatographic reactor is particularly advantageous to use as an alternative to RD, when the difference in the volatility of the species are small or the components are non-volatile or sensitive to temperature. The catalyst/adsorbent used for the chromatographic reactor may be same or a mixture of solid catalyst and adsorbent. Also, the catalyst itself may act both as a catalyst for the reaction mixture and an adsorbent for the separation. In spite of the considerable work in the last two decades, there are enough challenges posed by the reaction specific complexities and hence the field is still wide open for further research and development.

\section{Acknowledgement}

We wish to acknowledge the work of many postgraduate and post-doctoral researchers who have contributed to studies in our research groups over a period of many years. In particular, we would like to mention the important contributions of Dr Bhoja Reddy (IIT, Bombay), Dr Misbahu Ladan Mohammed (LSBU), Dr Dipesh Patel (LSBU), Dr Rene Mbeleck (LSBU), Dr

Krzysztof Ambroziak (Loughborough University), Dr. Praveen Ghodke (IIT, Bombay) and Victor Nnamdi Onyenkeadi (LSBU). 
Table 1. List of various reactive distillation applications based on ion exchange resins

\begin{tabular}{|c|c|c|}
\hline Application & Catalyst & Reference \\
\hline $\begin{array}{l}\text { Esters Synthesis } \\
\text { methyl acetate } \\
\text { methyl lactate } \\
\text { ethyl acetate } \\
n \text {-butyl acetate } \\
\\
i \text {-propyl acetate } \\
n \text {-propyl acetate } \\
n \text {-propyl propionate } \\
n \text {-amyl acetate } \\
i \text {-amyl acetate } \\
\text { 2-ethylhexyl acetate } \\
\text { 2-methyl propyl acetate } \\
n \text {-hexyl acetate } \\
n \text {-butyl acrylate } \\
\text { cyclohexene esterification } \\
\text { methyl dodecanoate }\end{array}$ & $\begin{array}{l}\text { Dowex } 50 \mathrm{~W} \text { X-8 } \\
\text { Amberlyst-15 } \\
\text { Dowex } 50 \mathrm{~W} \\
\text { Amberlyst-15 } \\
\text { cationic exchange resins (Indion 130, } \\
\text { Amberlyst } 15 \text { ) } \\
\text { Amberlyst-15W } \\
\text { Amberlyst-15 } \\
\text { Amberlyst } 46 \\
\text { Amberlyst-15 } \\
\text { cation exchange resins } \\
\text { (Indion } 130 \text {, amberlyst } 15 \text { ) } \\
\text { Amberlyst-15 } \\
\text { ion exchange resin } \\
\text { Amberlyst CSP2 } \\
\text { ion exchange resin } \\
\text { ion exchange resins } \\
\text { Amberlyst-15 }\end{array}$ & $\begin{array}{l}{[21]} \\
{[22]} \\
{[23]} \\
{[24,25]} \\
{[9,26]} \\
{[27]} \\
{[25]} \\
{[28]} \\
{[29]} \\
[9,25,30]] \\
{[31]} \\
{[32]} \\
{[33]} \\
{[34]} \\
{[35]} \\
{[36]}\end{array}$ \\
\hline $\begin{array}{l}\text { Etherification } \\
\text { methyl tert butyl ether (MTBE) } \\
\text { tert amyl methyl ether (TAME) } \\
\text { ethyl tert butyl ether (ETBE) } \\
\text { di isopropyl ether (DIPE) } \\
\text { 2-methoxy-2,4,4-trimethyl pentane } \\
\text { tert-amyl ethyl ether } \\
\text { methylal } \\
\text { ethylal } \\
\text { 3-methoxy-3-methylpentane } \\
\text { isobutyl tert-butyl ether }\end{array}$ & $\begin{array}{l}\text { Amberlyst-15 } \\
\text { Amberlite XAD } \\
\text { Amberlyst-15 } \\
\text { Amberlyst-36 } \\
\text { Amberlyst-35 } \\
\text { Amberlyst-15 } \\
\text { anion exchange resin } \\
\text { Indion 130 } \\
\text { cation exchange resins } \\
\text { ion exchange resins }\end{array}$ & $\begin{array}{l}{[37]} \\
{[38]} \\
{[39]} \\
{[40]} \\
{[41]} \\
{[42]} \\
{[43]} \\
{[44]} \\
{[45]} \\
{[46]}\end{array}$ \\
\hline $\begin{array}{l}\text { Hydrolysis } \\
\text { methyl acetate } \\
\text { methyl formate }\end{array}$ & $\begin{array}{l}\text { ion exchange resin } \\
\text { ion exchange resin }\end{array}$ & $\begin{array}{l}{[47]} \\
{[48]}\end{array}$ \\
\hline $\begin{array}{l}\text { Hydration/ Dehydration } \\
\text { ethylene oxide } \\
\text { isobutene }\end{array}$ & $\begin{array}{l}\text { cation/anion exchange resin } \\
\text { Amberlyst- } 15\end{array}$ & $\begin{array}{l}{[49]} \\
{[50]}\end{array}$ \\
\hline $\begin{array}{l}\text { Acetalisation } \\
\text { ethylene glycol } \\
\text { propylene glycol }\end{array}$ & $\begin{array}{l}\text { Amberite IR-120 } \\
\text { Amberite IR-120 }\end{array}$ & $\begin{array}{l}{[51]} \\
{[52]}\end{array}$ \\
\hline $\begin{array}{l}\text { Trans-esterification } \\
\text { butyl acetate from methyl acetate }\end{array}$ & Amberlyst-15 & [47] \\
\hline
\end{tabular}


Table 2. Catalysts used in the various applications of reactive distillation

\begin{tabular}{|c|c|c|c|c|c|}
\hline Catalyst & Application & $\begin{array}{l}\text { Temp, } \\
\text { Pressure }\end{array}$ & Performance & Remarks & Reference \\
\hline zeolites & $\begin{array}{l}\text { dehydration of } \\
\text { phenyl-ethanol to } \\
\text { produce styrene }\end{array}$ & $443 \mathrm{~K}$ & $\begin{array}{l}\text { higher yield of styrene is obtained by } \\
\text { medium-pore zeolite with smaller crystal } \\
\text { size particles; large pore zeolites show } \\
\text { similar activity but lesser selectivity }\end{array}$ & $\begin{array}{l}\text { formation of diphenylethyl } \\
\text { ethers reduces the selectivity } \\
\text { with large pore size zeolites }\end{array}$ & {$[53]$} \\
\hline lipase CALB enzyme & $\begin{array}{l}\text { trans esterification of } \\
\text { ethyl butyrate with } n \text { - } \\
\text { butanol }\end{array}$ & $\begin{array}{l}333 \mathrm{~K}, \text { abs } \\
15 \mathrm{kPa}\end{array}$ & conversion beyond equilibrium up to $98 \%$ & $\begin{array}{l}\text { enzymes are sensitive to } \\
\text { higher temperature }\end{array}$ & {$[54]$} \\
\hline $\begin{array}{l}\text { 1-(3-sulfopropyl)-3- } \\
\text { methylimidazolium } \\
\text { hydrogen sulfate ionic } \\
\text { liquid }\end{array}$ & $\begin{array}{l}\text { trans esterification of } \\
\text { sec-butyl acetate } \\
\text { (SBAC) with } \\
\text { methanol }\end{array}$ & $\begin{array}{l}338-373 \mathrm{~K}, 6 \\
\text { bar }\end{array}$ & $\begin{array}{l}\text { conversion up to } 97.72 \% \text { is achieved in } \\
\text { batch distillation }\end{array}$ & $\begin{array}{l}\text { easier catalyst separation } \\
\text { makes this process } \\
\text { environment friendly }\end{array}$ & {$[55]$} \\
\hline sodium methoxide & $\begin{array}{l}\text { trans esterification of } \\
\text { propylene carbonate } \\
\text { with methanol }\end{array}$ & $333-433 \mathrm{~K}$ & $\begin{array}{l}\text { sodium methoxide homogeneous catalyst } \\
\text { is only found to active enogh to do this } \\
\text { reaction in RD }\end{array}$ & $\begin{array}{l}\text { well known acidic/basic } \\
\text { heterogeneous catalysts are } \\
\text { not active enough for the } \\
\text { reaction }\end{array}$ & {$[82]$} \\
\hline $\begin{array}{l}\text { carbon nano tubes } \\
\text { with cobalt and iron } \\
\text { metals }\end{array}$ & $\begin{array}{l}\text { conversion of bio oils } \\
\text { to biodiesel }\end{array}$ & $388-493 \mathrm{~K}$ & $\begin{array}{l}\text { efficiency is increased and stability of } \\
\text { biodiesel is enhanced }\end{array}$ & $\begin{array}{l}\text { glycerol which is side product } \\
\text { also gets converted into } \\
\text { valuable chemical } \\
\text { simultaneously }\end{array}$ & [83] \\
\hline sulfated zirconia & $\begin{array}{l}\text { fatty acids } \\
\text { esterification }\end{array}$ & $\begin{array}{l}343-483 \mathrm{~K} \\
\text { and } 1 \mathrm{~atm}\end{array}$ & near complete conversion was achieved & $\begin{array}{l}\text { highly active and thermally } \\
\text { stable catalyst }\end{array}$ & [84] \\
\hline $\begin{array}{l}\text { 12-tungstophosphoric } \\
\text { acid }\end{array}$ & $\begin{array}{l}\text { synthesis of biodiesel } \\
\text { from waste cooking } \\
\text { oil }\end{array}$ & $1 \mathrm{~atm}$ & FAME yield up to $93.98 \%$ is achieved & $\begin{array}{l}\text { these are very active } \\
\text { heterogeneous catalysts }\end{array}$ & {$[85]$} \\
\hline $\begin{array}{l}2.5 \mathrm{wt} \% \mathrm{Cu} \text { on } \mathrm{h}-\mathrm{TS}-1 \\
\text { zeolite }\end{array}$ & $\begin{array}{l}\text { amination of benzene } \\
\text { to aniline }\end{array}$ & $343 \mathrm{~K}$ & $\begin{array}{l}12.4 \% \text { yield with } 84.7 \% \text { selectivity } \\
\text { towards aniline is obtained }\end{array}$ & & {$[86]$} \\
\hline $\begin{array}{l}\text { p-toluene sulfonic acid } \\
\text { supported on activated } \\
\text { carbon }\end{array}$ & bio oil up gradation & $\begin{array}{l}353 \mathrm{~K}, \text { abs } \\
20 \mathrm{kPa}\end{array}$ & $\mathrm{pH}$ value increased to 6 after up gradation & $\begin{array}{l}\text { acetic acid converted to ethyl } \\
\text { ester }\end{array}$ & {$[87]$} \\
\hline
\end{tabular}


Table 3. Catalysts used in various applications of reactive stripping

\begin{tabular}{|c|c|c|c|c|c|}
\hline Catalyst & Application & $\begin{array}{l}\text { Temperature } \\
\text { and pressure }\end{array}$ & Performance & Remarks & Reference \\
\hline $\mathrm{Pt}$ on $\mathrm{AlOOH}$ & $\begin{array}{l}\text { aqueous phase reforming } \\
\text { of sorbitol }\end{array}$ & $493 \mathrm{~K}, 35 \mathrm{bar}$ & $\begin{array}{l}\text { reaction is kinetically } \\
\text { controlled }\end{array}$ & $\begin{array}{l}\text { better mass transfer characteristics } \\
\text { in micro reactor imply reaction to } \\
\text { be kinetically controlled }\end{array}$ & [91] \\
\hline $\mathrm{Pt}-\mathrm{Ru}$ on $\mathrm{AlOOH}$ & $\begin{array}{l}\text { aqueous phase reforming } \\
\text { of sorbitol }\end{array}$ & $513 \mathrm{~K}, 35 \mathrm{bar}$ & $\begin{array}{l}\text { higher production rate than } \\
\text { monometallic catalyst }\end{array}$ & $\begin{array}{l}\text { synergy of catalyst design and } \\
\text { reactor design implies maximum } \\
\text { production rate }\end{array}$ & [92] \\
\hline $\begin{array}{l}\text { platinum-carbon-PTFE } \\
(0.001: 0.009: 0.99 \mathrm{w} / \mathrm{w})\end{array}$ & $\begin{array}{l}\text { catalytic exchange of } \\
\text { hydrogen isotopes }\end{array}$ & $333 \mathrm{~K}, 1.47$ bar & $\begin{array}{l}\text { enrichment of deuterium is } \\
\text { achieved }\end{array}$ & $\begin{array}{l}\text { customized wet proof catalyst } \\
\text { prevents activity and design of } \\
\text { catalyst favors gas liquid mass } \\
\text { transfer }\end{array}$ & [93] \\
\hline hydroxylated $\mathrm{MgF}_{2}$ & $\begin{array}{l}\text { dehydration of pentoses } \\
\text { and hexoses to furanic } \\
\text { aldehydes }\end{array}$ & $453 \mathrm{~K}, 10 \mathrm{bar}$ & $\begin{array}{l}\text { higher conversion and } \\
\text { selectivity compared to } \\
\text { other catalysts } \\
\text { Amberlyst70 and } \mathrm{Nb} 2 \mathrm{O} 5\end{array}$ & $\begin{array}{l}\text { control over acidic and basic sites } \\
\text { ration yield optimum conversion } \\
\text { and selectivity }\end{array}$ & [94] \\
\hline Amberlyst 70 & $\begin{array}{l}\text { dehydration of xylose to } \\
\text { furfural }\end{array}$ & $448 \mathrm{~K}, 8$ bar & high furfural yield & $\begin{array}{l}\text { Brønsted sites favor higher yield of } \\
\text { furfural }\end{array}$ & [95] \\
\hline $\mathrm{Nb}_{2} \mathrm{O}_{5}$ & $\begin{array}{l}\text { dehydration of xylose to } \\
\text { furfural }\end{array}$ & $448 \mathrm{~K}, 8$ bar & high xylose conversion & $\begin{array}{l}\text { Lewis sites favor higher } \\
\text { conversion of xylose }\end{array}$ & [95] \\
\hline $\begin{array}{l}\text { zeolite BEA (Si/AL } \\
=37.5)\end{array}$ & $\begin{array}{l}\text { esterification of } 1- \\
\text { octanol with hexanoic } \\
\text { acid }\end{array}$ & $428 \mathrm{~K}, 10 \mathrm{bar}$ & $\begin{array}{l}\text { complete conversion and } \\
\text { selectivity around } 94 \% \\
\text { towards ester; main side } \\
\text { reaction being } \\
\text { etherification of alcohol }\end{array}$ & $\begin{array}{l}\text { counter current stripping helps in } \\
\text { simultaneous removal of water } \\
\text { formation of ethers over the } \\
\text { strongly acidic catalytic sites }\end{array}$ & {$[96,97,98]$} \\
\hline $\begin{array}{l}\text { SAC13: Nafion/silica } \\
\text { composite with } 13 \%\end{array}$ & $\begin{array}{l}\text { esterification of } 1- \\
\text { octanol with hexanoic } \\
\text { acid }\end{array}$ & $428 \mathrm{~K}, 10 \mathrm{bar}$ & $\begin{array}{l}\text { complete conversion and } \\
\text { selectivity is around } 97 \% \\
\text { towards ester }\end{array}$ & $\begin{array}{l}\text { selectivity is improved compared } \\
\text { to zeolite catalysts }\end{array}$ & [97] \\
\hline
\end{tabular}




\begin{tabular}{|l|l|l|l|l|l|}
\hline Catalyst & Application & $\begin{array}{l}\text { Temperature } \\
\text { and pressure }\end{array}$ & Performance & Remarks & Reference \\
\hline Rhodium precursors & $\begin{array}{l}\text { decarbonylation of } \\
\text { aldehydes }\end{array}$ & $\begin{array}{l}453-473 \mathrm{~K}, 6.8- \\
12.5 \mathrm{bar}\end{array}$ & $\begin{array}{l}\text { improved in conversion } \\
\text { and selectivity due to } \\
\text { insitu stripping of CO }\end{array}$ & $\begin{array}{l}\text { many side reactions form carbonyl } \\
\text { complexes are reduced because of } \\
\text { less concentration of CO }\end{array}$ & [99] \\
\hline $\begin{array}{l}\text { Samarium nitrate } \\
\text { solution }\end{array}$ & $\begin{array}{l}\text { synthesis of dimethyl } \\
\text { carbonate (DMC) from } \\
\text { urea and methanol }\end{array}$ & $\begin{array}{l}453 \mathrm{~K}, 20-24 \\
\text { bar }\end{array}$ & $\begin{array}{l}\text { higher DMC selectivity } \\
(75 \%) \text { and methyl } \\
\text { carbanate (MC) conversion } \\
(34 \%)\end{array}$ & $\begin{array}{l}\text { efficient removal of ammonia and } \\
\text { DMC using superheated methanol } \\
\text { increases selectivity to DMC and } \\
\text { avoid dimethoxyethane (DME) } \\
\text { formation }\end{array}$ & [100] \\
\hline
\end{tabular}


Table 4. Catalysts used in the membrane reactor for different applications

\begin{tabular}{|c|c|c|c|c|c|c|}
\hline Catalyst & $\begin{array}{l}\text { Type of } \\
\text { Membrane }\end{array}$ & Application & $\begin{array}{l}\text { Temperature and } \\
\text { circulation velocity }\end{array}$ & Performance & Remarks & Reference \\
\hline $\begin{array}{l}\mathrm{KOH} \text { supported on } \\
\text { activated carbon }\end{array}$ & $\begin{array}{l}\text { micro porous } \\
\mathrm{TiO}_{2} / \mathrm{Al}_{2} \mathrm{O}_{3}\end{array}$ & biodiesel synthesis & $343 \mathrm{~K}, 0.21 \mathrm{~cm} / \mathrm{s}$ & $\begin{array}{l}94 \% \text { conversion of oil at } \\
\text { optimum reaction condition }\end{array}$ & $\begin{array}{l}\text { catalyst was reusable up to three } \\
\text { times but its activity reduces } \\
\text { from the fresh catalyst }\end{array}$ & [104] \\
\hline$p$-TSA/MCM-41 & $\begin{array}{l}\text { micro porous } \\
\text { ceramic }\end{array}$ & biodiesel synthesis & $353 \mathrm{~K}, 4.15 \mathrm{~mL} / \mathrm{min}$ & $\begin{array}{l}\text { highest biodiesel yield of } \\
84.1 \% \text { was obtained at } \\
\text { optimum reaction condition }\end{array}$ & $\begin{array}{l}\text { membrane pore size does not } \\
\text { have significant effect on } \\
\text { biodiesel yield }\end{array}$ & {$[105]$} \\
\hline Mg-Al hydrotalcites & $\begin{array}{l}\text { catalyst } \\
\text { embedded } \\
\text { membrane }\end{array}$ & biodiesel synthesis & $333 \mathrm{~K}$, batch reactor & $\begin{array}{l}\text { supported HT are twenty } \\
\text { times more active than } \\
\text { unsupported HT }\end{array}$ & $\begin{array}{l}\text { increase of membrane } \\
\text { hydrophobicity seems to } \\
\text { increase catalytic activity but } \\
\text { decrease FAME equilibrium } \\
\text { yield }\end{array}$ & {$[106]$} \\
\hline $\mathrm{Cr}_{2} \mathrm{O}_{3} / \mathrm{Al}_{2} \mathrm{O}_{3}$ & $\begin{array}{l}\text { packed-bed } \\
\text { catalytic } \\
\text { membrane } \\
\text { reactor }\end{array}$ & $\begin{array}{l}\text { dehydrogenation of } \\
\text { propane }\end{array}$ & $773 \mathrm{~K}$ and $0.1 \mathrm{M} \mathrm{Pa}$ & $\begin{array}{l}\sim 36 \% \text { conversion of propane } \\
\text { at } 773 \mathrm{~K}\end{array}$ & $\begin{array}{l}\text { separation of } \mathrm{H}_{2} \text { from } \\
\text { membrane double the } \\
\text { conversion from its equilibrium } \\
\text { value }\end{array}$ & {$[107]$} \\
\hline $\mathrm{Pt}(1 \mathrm{wt} \%) / \mathrm{SBA}-15$ & $\begin{array}{l}\text { hollow fiber } \\
\text { membrane } \\
\text { reactor }\end{array}$ & $\begin{array}{l}\text { dehydrogenation of } \\
\text { propane }\end{array}$ & $823 \mathrm{~K}$ & propane conversion $75.3 \%$ & $\begin{array}{l}\text { HFMR-II can be applied to } \\
\text { other catalytic reactions with } \\
\text { less coking problems, such as } \\
\text { the water gas shift reaction and } \\
\text { steam reforming etc. }\end{array}$ & {$[108]$} \\
\hline $\mathrm{Na}-\mathrm{W}-\mathrm{Mn} / \mathrm{SiO}_{2}$ & $\begin{array}{l}\text { ionic-electronic } \\
\text { conducting } \\
\text { membrane }\end{array}$ & $\begin{array}{l}\text { oxidative coupling } \\
\text { of methane }\end{array}$ & $\begin{array}{l}1173 \mathrm{~K} \text {, sweep gas } \\
\text { flow rate } 100 \\
\mathrm{~mL} / \mathrm{min}\end{array}$ & $\begin{array}{l}\text { yield of } \mathrm{C}_{2+} \text { as } 34.7 \%, \\
\text { methane conversion of } \\
51.6 \%, \mathrm{C} 2+\text { selectivity of } \\
67.4 \%\end{array}$ & & [109] \\
\hline $\mathrm{Mn}-\mathrm{W}-\mathrm{Na} / \mathrm{SiO}_{2}$ & $\begin{array}{l}\text { porous } \gamma- \\
\text { alumina } \\
\text { membrane }\end{array}$ & $\begin{array}{l}\text { oxidative coupling } \\
\text { of methane }\end{array}$ & $\begin{array}{l}1078 \mathrm{~K}, \mathrm{He} \text { flow } \\
212 \mathrm{~mL} / \mathrm{min}\end{array}$ & $\mathrm{C}_{2+}$ yields $27.5 \%$ & & [110] \\
\hline
\end{tabular}




\begin{tabular}{|c|c|c|c|c|c|c|}
\hline Catalyst & $\begin{array}{l}\text { Type of } \\
\text { Membrane }\end{array}$ & Application & $\begin{array}{l}\text { Temperature and } \\
\text { circulation velocity }\end{array}$ & Performance & Remarks & Reference \\
\hline Perovskite $\mathrm{SrTiO}_{3}$ & $\begin{array}{l}\text { dual-phase } \\
\text { composite } \\
\text { membrane } \\
\text { reactor }\end{array}$ & $\begin{array}{l}\text { partial oxidation of } \\
\text { methane to } \\
\text { synthesis gas }\end{array}$ & $\begin{array}{l}1223 \mathrm{~K} \text { and } \mathrm{CH}_{4} \\
\text { feed rate of } 20 \\
\mathrm{~mL} / \mathrm{min}\end{array}$ & $\begin{array}{l}74 \% \mathrm{CO} \text { and } 75 \% \mathrm{H}_{2} \\
\text { selectivity at } 17 \% \mathrm{CH}_{4} \\
\text { conversion }\end{array}$ & $\begin{array}{l}\text { catalytic performance strongly } \\
\text { depends on both reaction } \\
\text { temperature and } \mathrm{CH}_{4} \text { feed rate }\end{array}$ & [111] \\
\hline $\mathrm{Ni} / \mathrm{Al}_{2} \mathrm{O}_{3}$ & $\begin{array}{l}\text { ceramic } \\
\text { membrane } \\
\text { reactor }\end{array}$ & $\begin{array}{l}\text { partial oxidation of } \\
\text { methane to } \\
\text { synthesis gas }\end{array}$ & $\begin{array}{l}1073 \mathrm{~K}, \\
\text { atmospheric } \\
\text { pressure }\end{array}$ & $96.4 \%$ methane conversion & $\begin{array}{l}\text { at higher pressures, a decrease } \\
\text { in the methane conversion takes } \\
\text { place, due to the unfavorable } \\
\text { equilibrium shift }\end{array}$ & [112] \\
\hline $\begin{array}{l}\text { Ru deposited on } \\
\text { membrane }\end{array}$ & $\begin{array}{l}\text { Ru deposited } \\
\text { ceramic } \\
\text { membrane } \\
\text { reactor }\end{array}$ & $\begin{array}{l}\text { partial oxidation of } \\
\text { methane to } \\
\text { synthesis gas }\end{array}$ & $773 \mathrm{~K}, 0.12 \mathrm{MPa}$ & $59 \%$ methane conversion & $\begin{array}{l}\text { methane conversion is higher } \\
\text { than equilibrium conversion } \\
(54 \%)\end{array}$ & [113] \\
\hline $\begin{array}{l}0.6 \% \mathrm{Ru} \text { on } \mathrm{La}_{2} \mathrm{O}_{3} \text { and } \\
\mathrm{SiO}_{2}\end{array}$ & $\begin{array}{l}\text { Pd-Ag } \\
\text { membrane }\end{array}$ & $\begin{array}{l}\text { dry reforming of } \\
\text { methane }\end{array}$ & $\begin{array}{l}823 \mathrm{~K}, 10-70 \\
\mathrm{~mL} / \mathrm{min}\end{array}$ & $\begin{array}{l}\mathrm{Ru} / \mathrm{La}_{2} \mathrm{O}_{3}(50 \mathrm{wt} \%)-\mathrm{SiO}_{2}, \\
\text { exhibited the highest turnover } \\
\text { frequency, having } 38 \% \mathrm{Ru} \\
\text { dispersion }\end{array}$ & $\begin{array}{l}\mathrm{La}_{2} \mathrm{O}_{3} \text { and } \mathrm{SiO}_{2} \text { supports imply } \\
\text { stable and active support }\end{array}$ & [114] \\
\hline $\begin{array}{l}0.3 \% \mathrm{Pt}-\mathrm{Ru} \text { on detonation } \\
\text { nanodiamonds }\end{array}$ & $\begin{array}{l}\text { Pd-Ru } \\
\text { membrane }\end{array}$ & $\begin{array}{l}\text { ethanol steam } \\
\text { reforming }\end{array}$ & $\begin{array}{l}\text { 623-923 K, } 20 \\
\mathrm{~mL} / \mathrm{min}\end{array}$ & $\begin{array}{l}\text { Pt-Ru catalysts perform better } \\
\text { than Pt-Ni catalysts }\end{array}$ & & [115] \\
\hline $\begin{array}{l}\mathrm{CuO} / \mathrm{ZnO} / \mathrm{Al}_{2} \mathrm{O}_{3} \\
\text { catalyst }\end{array}$ & $\begin{array}{l}\mathrm{Al}_{2} \mathrm{O}_{3} \text { supported } \\
\mathrm{Pd} \text { based } \\
\text { membrane }\end{array}$ & $\begin{array}{l}\text { Methanol steam } \\
\text { reforming }\end{array}$ & $\begin{array}{l}553-603 \mathrm{~K}, 22 \\
\mathrm{~mL} / \mathrm{min}\end{array}$ & $\begin{array}{l}\text { highly pure hydrogen is } \\
\text { produced with } 85 \% \text { methanol } \\
\text { conversion }\end{array}$ & $\begin{array}{l}\text { Pd based membranes has long } \\
\text { life time }\end{array}$ & [116] \\
\hline $\begin{array}{l}\mathrm{Pt} / 20 \% \mathrm{CeZrO}_{2} / \mathrm{Al}_{2} \mathrm{O}_{3} \\
\text { catalyst }\end{array}$ & $\begin{array}{l}\text { Pd-Ag } \\
\text { membrane }\end{array}$ & $\begin{array}{l}\mathrm{CO}_{2} \text { reforming of } \\
\text { methane }\end{array}$ & $\begin{array}{l}823 \mathrm{~K}, 10-90 \\
\mathrm{ml} / \mathrm{min}\end{array}$ & $\begin{array}{l}\text { conversion is } 60 \% \text { higher } \\
\text { than in fixed bed with } 75 \% \\
\text { hydrogen recovery }\end{array}$ & $\begin{array}{l}\text { catalyst with } 20 \% \mathrm{CeZrO}_{2} \text { on } \\
\text { alumina is a stable formulation }\end{array}$ & [117] \\
\hline nickel membrane & $\begin{array}{l}\text { nickel alumina } \\
\text { membrane }\end{array}$ & $\begin{array}{l}\text { combined steam } \\
\text { and } \mathrm{CO}_{2} \text { reforming } \\
\text { of methane }\end{array}$ & 923-1023 K & $\begin{array}{l}\text { conversions up to } 96 \% \text { was } \\
\text { achieved }\end{array}$ & $\begin{array}{l}\text { carbon deposition was not } \\
\text { observed }\end{array}$ & {$[118]$} \\
\hline $1 \% \mathrm{Pd} / \mathrm{CuOZnO}$ catalyst & Pd membrane & $\begin{array}{l}\text { steam reforming of } \\
\text { methanol }\end{array}$ & $583 \mathrm{~K}$ & $\begin{array}{l}\text { reaction rate is } 50-100 \% \\
\text { faster than for reaction } \\
\text { without Pd-membrane }\end{array}$ & $\begin{array}{l}\text { hydrogen spill over from the } \\
\text { catalysts to membrane favors } \\
\text { catalytic activity }\end{array}$ & [119] \\
\hline
\end{tabular}


Table 5. Some of the applications of chromatographic reactors

\begin{tabular}{|c|c|c|}
\hline Systems & Catalyst/Adsorbent & References \\
\hline Biosynthesis of dextran from sucrose & Dextransucrose & [161] \\
\hline Esterification of acetic acid and butyl cellosolve & Amberlyst-15 & [162] \\
\hline Esterification of acetic acid and ethanol (ethyl acetate synthesis) & Amberlyst-15 & [126] \\
\hline $\begin{array}{l}\text { Esterification of acetic acid with ethanol / methanol (ethyl acetate / methyl } \\
\text { acetate synthesis) }\end{array}$ & Finex KEF76 & [163] \\
\hline Esterification of acetic acid and 2-ethylhexanol (2-ethylhexyl acetate synthesis) & Amberlyst-15 & [137] \\
\hline Esterification of acetic acid and glycerol (glycerine acetate synthesis) & Amberlyst-15 & [135] \\
\hline Esterification of acetic acid and $n$-hexanol ( $n$-hexyl acetate synthesis) & Purolite ${ }^{\circledR}$ CT-124 & {$[144,145,146 \mathrm{a}, 146 \mathrm{~b}]$} \\
\hline Esterification of acetic acid and methanol (methyl acetate synthesis) & Amberlyst-15 & {$[149,153]$} \\
\hline $\begin{array}{l}\text { Esterification of acetic acid and } \beta \text {-phenethyl alcohol ( } \beta \text {-phenethyl acetate } \\
\text { synthesis) }\end{array}$ & $\begin{array}{l}\text { Proton type ion } \\
\text { exchange resins }\end{array}$ & [128] \\
\hline Esterification of acetic acid and $n$-propanol ( $n$-propyl acetate synthesis) & Amberlyst-15 & [138] \\
\hline Esterification of acrylic acid and methanol (methyl acrylate synthesis) & Amberlyst-15 & [136] \\
\hline Esterification of lactic acid and ethanol (ethyl lactate synthesis) & Amberlyst-15 & {$[164]$} \\
\hline Hydrogenation of 1,3.5-trimethyl benzene & $\begin{array}{l}\text { Platinum supported } \\
\text { on alumina }\end{array}$ & {$[165,166]$} \\
\hline Hydrolysis of methyl formate & Dowex 50W-X8 & [160] \\
\hline Hydrolysis of methyl acetate / methyl formate & Dowex 50W-X8 & [159] \\
\hline Inversion of sucrose & Invertase & [167] \\
\hline Lactosucrose synthesis & $\beta$-fructofuranosidase & [168] \\
\hline Methanol synthesis from syngas & Metal catalyst & [130] \\
\hline Oxidative coupling of methane & Oxide type of catalyst & [169] \\
\hline Isomerisation of glucose & Immobilized isomerise & [170] \\
\hline Isomerisation of $p$-xylene & ZSM-4 & [171] \\
\hline Synthesis of Acetals from acetaldehyde and ethanol/butanol & Amberlyst-15 & [172] \\
\hline Synthesis of bisphenol-A from acetone and excess phenol & Amberlyst-31 & [127] \\
\hline
\end{tabular}


Synthesis of diethylacetal from acetaldehyde and ethanol

Synthesis of diethylacetal from acetaldehyde and methanol

Synthesis of MTBE
Amberlyst-15

Amberlyst-15

Amberlyst-15
[173,174]

[175]

[31] 


\section{References}

[1] Agar DW. Multifunctional reactors : Old preconceptions and new dimensions. Chem Eng Sci 1999,54:1299-305.

[2] Sharma MM, Mahajani SM. Industrial applications of reactive distillation in reactive distillation: Status and future directions. Weinheim, Germany, Wiley VCH, 2003.

[3] Ertl G, Knozinger H, Weitkamp J. Handbook of heterogeneous catalysis volume 3. Weinheim, Germany, Wiley VCH, 1997.

[4] Noeres C, Kenig EY, Gorak A. Modelling of reactive separation processes: Reactive absorption and reactive distillation. Chem Eng Process 2003,42:157-78.

[5] Sundmacher K, Rihko LK, Hoffmann U. Classification of reactive distillation processes by dimensionless numbers. Chem Eng Commun 1994,127:151-67.

[6] Agreda VH, Partin LR. Reactive distillation process for the production of methyl acetate, US 4,435,595 (Patent)1984.

[7] Krishna R, Baten JMV, Ellenberger J, Higler AP, Taylor R. CFD simulations of sieve tray hydrodynamics. Chem Eng Res Des 1999,77:639-44.

[8] Taylor R, Krishna R. Modelling reactive distillation. Chem Eng Sci 2000,55:5183-229.

[9] Saha B, Chopade SP, Mahajani SM. Recovery of dilute acetic acid through esterification in a reactive distillation column. Catal Today 2000,60:147-57.

[10] Moritz P, Hasse H. Fluid dynamics in reactive distillation packing katapak-s. Chem Eng Sci 1999,54:1367-74.

[11] Lebens PJM, Kapteijn F, Sie ST, Moulijn JA. Potentials of internally finned monoliths as a packing for multifunctional reactors. Chem Eng Sci 1999,54:1359-65.

[12] Trubac RE, Dautzenberg FM, Griffin TA, Paikert B, Schmidt VR, Overbeek RA. Microengineered catalyst systems : ABB's advancement in structured catalytic packings. Catal Today 2001,69:17-24.

[13] Quang D V, Amigues P, Gaillard J, Leonard J, Nocca J. Process for manufacturing a tertiary alkyl ether by reactive distillation, US4847430 (Patent)1989.

[14] Sundmacher K, Hoffmann U. Multicomponent mass and energy transport on different length scales in a packed reactive distillation column for heterogeneously catalysed fuel ether production. Chem Eng Sci 1994,49:4443-64. 
[15] Wang EQ, Li CY, Wen LY, Du ZX, Zhang YQ. Simulation of cumene synthesis by suspension catalytic distillation. Adv Mater Res 2012,557-559,2243-8.

[16] Lei Z, Li C, Li J, Chen B. Suspension catalytic distillation of simultaneous alkylation and transalkylation for producing cumene. Sep Purif Technol 2004,34:265-71.

[17] Wang E, Li C, Wen L, Min E. Study on suspension catalytic distillation for synthesis of linear alkylbenzene. AIChE J 2005,51:845-53.

[18] Erqiang W, Chengyue L. Simulation of suspension catalytic distillation for synthesis of linear alkylbenzene. Chinese J Chem Eng 2003,11:520-5.

[19] Han SJ, Jin Y, Yu ZQ. Application of a fluidized reaction-distillation column for hydrolysis of methyl acetate. Chem Eng J 1997,66:227-30.

[20] Hiwale RS, Bhate N V, Mahajan YS, Mahajani SM. Industrial applications of reactive distillation: Recent trends industrial applications of reactive distillation: Recent trends. Int J Chem Kinet 2004,2:1-52.

[21] Nuemann R, Sasson Y. Recovery of dilute acetic acid by esterification in a packed chemorectification column. Ind Eng Chem Process Des Dev 1984,23:654-9.

[22] Pöpken T, Steinigeweg S, Gmehling J. Synthesis and hydrolysis of methyl acetate by reactive distillation using structured catalytic packings: experiments and simulation. Ind Eng Chem Res 2001,40:1566-74.

[23] Choi JI, Hong WH. Recovery of lactic acid by batch distillation with chemical reactions using ion exchange resin. J Chem Eng Japan 1999,32:184-9.

[24] Calvar N, González B, Dominguez A. Esterification of acetic acid with ethanol: Reaction kinetics and operation in a packed bed reactive distillation column. Chem Eng Process 2007,46:1317-23.

[25] Patidar P, Mahajani SM. Esterification of fusel oil using reactive distillation - part I: reaction kinetics. Chem Eng J 2012,207-208,377-87.

[26] Gangadwala J, Mankar S, Mahajani S, Kienle A, Stein E. Esterification of acetic acid with butanol in the presence of ion-exchange resins as catalysts. Ind Eng Chem Res 2003,42:2146-55.

[27] Gadewar SB, Malone MF, Doherty MF. Feasible region for a countercurrent cascade of vapor-liquid CSTRs. AIChE J 2002,48:800-14.

[28] Buchaly C, Kreis P, Andrzej G. n-Propyl propionate synthesis via catalytic distillation experimental investigation in pilot-scale. Ind Eng Chem Res 2012,51:891-9. 
[29] Chiang S, Kuo C, Yu C, Wong DSH. Design alternatives for the amyl acetate process : Coupled reactor/column and reactive distillation. Ind Eng Chem Res 2002,41:3233-46.

[30] Saha B, Teo HTR, Alqahtani, A. iso-Amyl acetate synthesis by catalytic distillation, International Journal of Chemical Reactor Engineering 2005, 3 (A 11), 1-14.

[31] Patidar P, Mahajani S. Entrainer-based reactive distillation for the synthesis of 2ethylhexyl acetate. Ind Eng Chem Res 2012,51:8748-59.

[32] Smejkal Q, Hanika J, Kolena J. 2-Methylpropylacetate synthesis in a system of equilibrium reactor and reactive distillation column. Chem Eng Sci 2001,56:365-70.

[33] Schmitt M, Hasse H, Althaus K, Schoenmakers H, Götze L, Moritz P. Synthesis of nhexyl acetate by reactive distillation. Chem Eng Process 2004,43:397-409.

[34] Zeng KL, Kuo CL, Chien IL. Design and control of butyl acrylate reactive distillation column system. Chem Eng Sci 2006,61:4417-31.

[35] Saha B, Sharma MM. Esterification of formic acid, acrylic acid and methacrylic acid with cyclohexene in batch and distillation column reactors : Ion-exchange resins as catalysts. React Funct Polym 1996,28:263-78.

[36] Steinigeweg S, Gmehling J. Esterification of a fatty acid by reactive distillation. Ind Eng Chem Res 2003,42:3612-9.

[37] Jacobs R, Krishna R. Multiple solutions in reactive distillation for methyl tert-butyl ether synthesis. Ind Eng Chem Process Des Dev 1993,32:1706-9.

[38] Bravo JL, Pyhalahti A. Investigations in a catalytic distillation pilot plant: Vapor/liquid equilibrium, kinetics, and mass-transfer issues. Ind Eng Chem Res 1993,32:2220-5.

[39] Oudshoom OL, Janissen M, Kooten WEJ Van, Jansen J, Bekkuin H Van, Bleek CM Van Den, et al. A novel structured catalyst packing for catalytic distillation of ETBE. Chem Eng Sci 1999,54:1413-8.

[40] Marker TL, Funk GA, Barker PT, Hammershaimb HU. Two-stage process for producing diisopropyl ether using catalytic distillation, US5,744,645 (Patent) 1998.

[41] Rihko-Struckmann LK, Karinen RS, Jakobsson K, Aittamaa JR. Process configurations for the production of the 2-methoxy-2, 4, 4- trimethylpentane - a novel gasoline oxygenate. Chem Eng Process 2004,43:57-65.

[42] Aiouache F, Goto S. Reactive distillation-pervaporation hybrid column for tert-amyl alcohol etherification with ethanol. Chem Eng Sci 2003,58:2465-77. 
[43] Hagen GP, Spangler MJ. Preparation of polyoxymethylene dialkane ethers, by catalytic conversion of formaldehyde formed by dehydrogenation of methanol or dimethyl ether. US6,350,919 (Patent) 2002.

[44] Chopade SI, Sharma MM. Reaction of ethanol and formaldehyde : Use of versatile cationexctiange resins as catalyst in batch reactors and reactive distillation columns. React Funct Polym 1997,32:53-64.

[45] Hendriksen DE, Mcglamery GG, Keenan, Michael J, Pete DD. Process for preparing 3methyl-2- pentene. US5731486 (Patent) 1998.

[46] Bessling B, Knab W, Brox W, Lohe B. Method and device for obtaining isobutenes from conjugated hydrocarbons. US6,362,386 (Patent) 2002.

[47] Jimenez L, Costa-Lopez J. The production of butyl acetate and methanol via reactive and extractive distillation. II Process modeling, dynamic simulation and control strategy. Ind Eng Chem Res 2002,41:6735-44.

[48] Saari K, Tirronen E, Vuori A, Lahtinen M. Method for preparing formic acid. US6,429,333 (Patent) 2002.

[49] Ciric AR, Miao P. Steady state multiplicities in an ethylene glycol reactive distillation column. Ind Eng Chem Res 1994,33:2738-48.

[50] Zhang CM, Adesina AA, Wainwright MS. Isobutene hydration over Amberlyst-15 in a slurry reactor. Chem Eng Process 2003,42:985-91.

[51] Chopade SP, Sharma MM. Acetalization of ethylene glycol with formaldehyde using cation-exchange resins as catalysts : Batch versus reactive distillation. React Funct Polym 1997,34:37-45.

[52] Broekhuis RR, Lynn S, King CJ. Recovery of propylene glycol from dilute aqueous solutions via reversible reaction with aldehydes. Ind Eng Chem Res 1994,33:3230-7.

[53] Lange J, Otten V. Dehydration of phenyl-ethanol to styrene : Zeolite catalysis under reactive distillation 2006,238:6-12.

[54] Heils R, Sont A, Bubenheim P, Liese A, Smirnova I. Integration of enzymatic catalysts in a reactive distillation column with structured packings. Ind Eng Chem Res 2012,51:11482-9.

[55] Wang H, Wu C, Bu X, Tang W, Li L, Qiu T. A benign preparation of sec-butanol via transesterification from sec-butyl acetate using the acidic Imidazolium ionic liquids as catalysts. Chem Eng J 2014,246:366-72. 
[56] Liu Y, Yang B, Li S. Process simulation based on experimental investigations for 3methylthiophene alkylation with isobutylene in a reactive distillation column. Ind Eng Chem Res 2012,51:9803-11.

[57] Zekai Z, Hui J, Shenglin L, Qingxia W, Longya X. Alkylation performance of thiophene and its derivatives during olefinic alkylation of thiophenic sulfur in gasoline. Chinese $\mathbf{J}$ Catal 2006,27:309-13.

[58] Bellie V, Geantet C, Vrinat M. Alkylation of 3-methylthiophene with 2-methyl-2-butene over a zeolitic Catalyst. Energy \& Fuels 2004,18:1806-13.

[59] Dupuy B, Laforge S, Morais C, Bachmann C, Magnoux P, Richard F. Alkylation of 3methylthiophene by 2-methyl-1-pentene over HY, HBEA and HMCM-22 acidic zeolites. Appl Catal A Gen 2012,413-414,192-204.

[60] Richard F, Boita T, Moreau M, Bachmann C, Pérot G. Transformation of thiophenic compounds over HY zeolite: Study of the acid-catalyzed isomerization and disproportionation mechanisms by quantum chemical calculations. J Mol Catal A Chem 2007,273:48-54.

[61] Dupuy B, Laforge S, Bachmann C, Magnoux P, Richard F. Desulfurization of model FCC feedstocks by alkylation: Transformation of thiophenic compounds in presence of 2methyl-1-pentene over acidic zeolites. J Mol Catal A Chem 2012,363-364,273-82.

[62] Wang R, Li Y. Preparation of MCM-41 supported phosphoric acid catalyst for thiophenic compounds alkylation in FCC gasoline. Catal Commun 2010,11:705-9.

[63] Shi R, Li Y, Wang R, Guo B. Alkylation of thiophenic compounds with olefins and its kinetics over MCM-41 supported phosphoric acid in FCC gasoline. Catal Letters 2010,139:114-22.

[64] Liu Y, Yi CH, Hu JY, Yang BL. Gasoline desulfurization with two catalytic distillation columns. Adv Mater Res 2012,550-553,550-3.

[65] Guo B, Wang R, Li Y. The performance of solid phosphoric acid catalysts and macroporous sulfonic resins on gasoline alkylation desulfurization. Fuel Process Technol 2010,91:1731-5.

[66] Ha Y, Guo B, Li Y. Sensitivity and economic analysis of a catalytic distillation process for alkylation desulfurization of fluid catalytic cracking (FCC) gasoline. J Chem Technol Biotechnol 2014,accepted.

[67] Guo B, Li Y. Analysis and simulation of reactive distillation for gasoline alkylation desulfurization. Chem Eng Sci 2012,72:115-25. 
[68] Arias M, Laurenti D, Bellière V, Geantet C, Vrinat M, Yoshimura Y. Preparation of supported H3PW12O40.6H2O for thiophenic compounds alkylation in FCC gasoline. Appl Catal A Gen 2008,348:142-7.

[69] Xu C, Yang K, Liu Z, Qin Z, He W, Dai Q, et al. Superparamagnetic supported catalyst $\mathrm{H} 3 \mathrm{PW} 12 \mathrm{O} 40 / \gamma-\mathrm{Fe} 2 \mathrm{O} 3$ for alkylation of thiophene with olefine. Chinese J Chem Eng 2014,22:305-11.

[70] Richard F, Célérier S, Vilette M, Comparot JD, Montouillout V. Alkylation of thiophenic compounds over heteropoly acid H3PW12O40 supported on MgF2. Appl Catal B Environ 2014,152-153,241-9.

[71] Mbeleck R, Ambroziak K, Saha B, Sherrington DC. Stability and recycling of a polymersupported Mo(VI) alkene epoxidation catalyst. Reactive and Functional Polymers 2007, 67, 1448-1457.

[72] Ambroziak K, Mbeleck R, Saha B, Sherrington DC. Epoxidation of limonene by tert-butyl hydroperoxide catalyzed by polybenzimidazole-supported Mo(VI) complex. Journal of Ion Exchange 2007, 18 (4), 452-457.

[73] Ambroziak K, Mbeleck R, Saha B, Sherrington D C.Greener and sustainable method for alkene epoxidations by polymer-supported Mo(VI) catalysts. International Journal of Chemical Reactor Engineering 2010, 8 (A125), 1-13.

[74] Mohammed M L, Patel D, Mbeleck R., Niyogi D, Sherrington DC, Saha B. Optimisation of alkene epoxidation catalysed by polymer supported Mo(VI) complexes and application of artificial neural network for the prediction of catalytic performances. Applied Catalysis A 2013, 466, 142-152.

[75] Mohammed ML, Mbeleck R, Patel D, Sherrington DC, Saha B. Greener route to 4-vinyl1-cyclohexane 1,2-epoxide synthesis using batch and continuous reactors. Green Processing and Synthesis 2014, 3, 411-418.

[76] Ambroziak K, Mbeleck R, He Y, Saha B, Sherrington DC. Investigations of batch alkenes epoxidation catalayzed by novel polymer-supported Mo(VI) complexes. Industrial and Engineering Chemistry Research 2009, 48, 3293-3302.

[77] Mohammed ML, Patel D, Mbeleck R, Niyogi D, Sherrington DC, Saha B, Greener and efficient epoxidation of 4-vinyl-1-cyclohexene with polystyrene 2-(aminomethyl)pyridine supported Mo(VI) catalyst in batch and continuous reactors. Chemical Engineering Research and Design 2015, 94, 194-203.

[78] Mbeleck R, Mohammed ML, Ambroziak K, Sherrington DC, Saha B. Efficient epoxidation of cyclododecene and dodecene catalysed by polybezimidazole-supported Mo(VI) complex. Catalysis Today 2015a, in press, doi http://dx.doi.org/10.1016/j.cattod.2014.12.029. 
[79] Oku N, Seo T. Process for producing propylene oxide. US6646138 (Patent) 2003.

[80] Saha B, Ambroziak K, Sherrington DC, Mbeleck R. Liquid phase epoxidation process. US8,759,552 B2 (Patent) 2014.

[81] Saha B, Ambroziak K, Sherrington DC, Mbeleck R. A continuous process for the liquid phase epoxidation of an olefinic compound with an oxidant. ZL201080044175.2 (Patent) 2015.

[82] Holtbruegge J, Leimbrink M, Lutze P, Górak A. Synthesis of dimethyl carbonate and propylene glycol by transesterification of propylene carbonate with methanol. Catalyst screening, chemical equilibrium and reaction kinetics. Chem Eng Sci 2013,104:347-60.

[83] Zhang D, Wei D, Ding W, Zhang X. Carbon-based nanostructured catalyst for biodiesel production by catalytic distillation. Catal Commun 2014,43:121-5.

[84] Kiss AA, Rothenberg G. Sustainable biodiesel production by catalytic reactive distillation in catalysis of organic reactions. Taylor \& Francis, USA, 2009.

[85] Noshadi I, Amin NAS, Parnas RS. Continuous production of biodiesel from waste cooking oil in a reactive distillation column catalyzed by solid heteropolyacid: Optimization using response surface methodology (RSM). Fuel 2012,94:156-64.

[86] Yu T, Zhang Q, Xia S, Li G, Hu C. Direct amination of benzene to aniline by reactive distillation method over copper doped hierarchical TS-1 catalyst. Catal Sci Technol 2014,4:639-47.

[87] Wang C, Hu Y, Chen Q, Lv C, Jia S. Bio-oil upgrading by reactive distillation using ptoluene sulfonic acid catalyst loaded on biomass activated carbon. Biomass and Bioenergy 2013,56:405-11.

[88] Mueller I, Schildhauer TJ, Madrane A, Kapteijn F, Moulijn JA, Kenig EY. Experimental and theoretical study of reactive stripping in monolith reactors. Ind Eng Chem Res 2007,46:4149-57.

[89] Yu S, Zhou A, Tan Q. Simulation of multistage catalytic stripping with a nonequilibrium stage model. Comput Chem Eng 1997,21:409-15.

[90] Sundmacher K, Kienle A, Seidel-Morgenstern A. Integrated chemical processes. Weinheim, Germany, Wiley-VCH, 2005.

[91] D’Angelo MFN, Ordomsky V, Van der Schaaf J, Schouten JC, Nijhuis TA. Aqueous phase reforming in a microchannel reactor: The effect of mass transfer on hydrogen selectivity. Catal Sci Technol 2013,3:2834-42. 
[92] Neira D’Angelo MF, Ordomsky V, Van der Schaaf J, Schouten JC, Nijhuis TA. Continuous hydrogen stripping during aqueous phase reforming of sorbitol in a washcoated microchannel reactor with a Pt-Ru bimetallic catalyst. Int J Hydrogen Energy 2014,39:18069-76.

[93] Kumar R, Mohan S, Mahajani SM. Reactive stripping for the catalytic exchange of hydrogen isotopes. Ind Eng Chem Res 2013,52:10935-50.

[94] Agirrezabal-Telleria I, Guo Y, Hemmann F, Arias PL, Kemnitz E. Dehydration of xylose and glucose to furan derivatives using bifunctional partially hydroxylated $\mathrm{MgF} 2$ catalysts and N2-stripping. Catal Sci Technol 2014,4:1357-68.

[96] Nijhuis TA, Beers AEW, Kapteijn F, Moulijn JA. Water removal by reactive stripping for a solid-acid catalyzed esteriÿcation in a monolithic reactor. Chem Eng Sci 2002,57:162732 .

[97] Beers AEW, Spruijt RA, Nijhuis TA, Kapteijn F, Moulijn JA. Esterification in a structured catalytic reactor with counter-current water removal. Catal Today 2001,66:17581.

[98] Schildhauer TJ, Hoek I, Kapteijn F, Moulijn JA. Zeolite BEA catalysed esterification of hexanoic acid with 1-octanol: Kinetics, side reactions and the role of water. Appl Catal A Gen 2009,358:141-5.

[99] Gutmann B, Elsner P, Glasnov T, Roberge DM, Kappe CO. Shifting chemical equilibria in flow-efficient decarbonylation driven by annular flow regimes. Angew Chem Int Ed Engl 2014,126:11741-5.

[100] Ranade VV, Kelkar AA, Pane VH, Kinage AK, Shingote SK, Roy LS. Synthesis of methyl carbamate and dimethyl carbonate (DMC) in presence of stripping with inert gas or superheated vapours and reactor for the same. WO2014072803A1 (Patent) 2014.

[101] Butler JP. Hydrogen isotope separation by catalyzed exchange between hydrogen and liquid water. Sep Sci Technol 1980,15:371-96.

[102] Armor JN. Overcoming equilibrium limitations in chemical processes. Appl Catal A Gen 2001,222:91-9.

[103] Seidel-morgenstern A. Membrane reactors: Distributing reactants to imptove selectivity and yield. Weinheim, Germany, Wiley VCH, 2010.

[104] Baroutian S, Aroua MK, Raman AA A, Sulaiman NMN. A packed bed membrane reactor for production of biodiesel using activated carbon supported catalyst. Bioresour Technol 2011,102:1095-102. 
[105] Xu W, Gao L, Wang S, Xiao G. Biodiesel production in a membrane reactor using MCM41 supported solid acid catalyst. Bioresour Technol 2014,159:286-91.

[106] Guerreiro L, Pereira PM, Fonseca IM, Martin-Aranda RM, Ramos AM, Dias JML, et al. PVA embedded hydrotalcite membranes as basic catalysts for biodiesel synthesis by soybean oil methanolysis. Catal Today 2010,156:191-7.

[107] Weyten H, Keizer K, Kinoo A, Luyten J, Leysen R. Dehydrogenation of propane using a packed-bed catalytic membrane reactor. AIChE J 1997,43:1819-27.

[108] Gbenedio E, Wu Z, Hatim I, Kingsbury BFK, Li K. A multifunctional Pd/alumina hollow fibre membrane reactor for propane dehydrogenation. Catal Today 2010,156:93-9.

[109] Bhatia S, Thien CY, Mohamed AR. Oxidative coupling of methane (OCM) in a catalytic membrane reactor and comparison of its performance with other catalytic reactors. Chem Eng J 2009, 148:525-32.

[110] Lu Y, Dixon AG, Moser WR, Ma YH. Oxidative coupling of methane in a modified $\gamma$ alumina membrane reactor. Chem Eng Sci 2000,55:4901-12.

[111] Tian T, Wang W, Zhan M, Chen C. Catalytic partial oxidation of methane over SrTiO3 with oxygen-permeable membrane reactor. Catal Commun 2010;11:624-8.

[112] Santos A, Coronas J, Santamaria J. Catalytic partial oxidation of methane to synthesis gas in a ceramic membrane reactor. Catal Letters 1995,30:189-99.

[113] Paturzo L, Gallucci F, Basile A, Pertici P, Scalera N, Vitulli G. Partial oxidation of methane in a catalytic Ruthenium membrane reactor. Ind Eng Chem Res 2003,42:296874.

[114] Faroldi BM, Lombardo E A, Cornaglia LM. Ru/La2O3-SiO2 catalysts for hydrogen production in membrane reactors. Catal Today 2011,172:209-17.

[115] Mironova EY, Ermilova MM, Orekhova NV, Muraviev DN, Yaroslavtsev AB. Production of high purity hydrogen by ethanol steam reforming in membrane reactor. Catal Today 2014,236:64-9.

[116] Liguori S, Iulianelli A, Dalena F, Piemonte V, Huang Y, Basile A. Methanol steam reforming in an $\mathrm{Al} 2 \mathrm{O} 3$ supported thin Pd-layer membrane reactor over $\mathrm{Cu} / \mathrm{ZnO} / \mathrm{Al} 2 \mathrm{O} 3$ catalyst. Int J Hydrogen Energy 2014,39:18702-10.

[117] Silva F A, Hori CE, da Silva AM, Mattos LV, Múnera J, Cornaglia L, et al. Hydrogen production through $\mathrm{CO} 2$ reforming of $\mathrm{CH} 4$ over $\mathrm{Pt} / \mathrm{CeZrO} 2 / \mathrm{Al} 2 \mathrm{O} 3$ catalysts using a $\mathrm{Pd}-$ Ag membrane reactor. Catal Today 2012,193:64-73. 
[118] Ryi SK, Lee SW, Park JW, Oh DK, Park JS, Kim SS. Combined steam and CO2 reforming of methane using catalytic nickel membrane for gas to liquid (GTL) process. Catal Today 2014,236:49-56.

[119] Rei BMH, Yeh GT, Pan CW. Catalysis-spillover-membrane-2 [1]. The rate enhancement of methanol steam reforming reaction in a membrane catalytic reactor. Catal Today 2004,97:167-72.

[120] Wu Z, Hatim IMD, Kingsbury BFK, Gbenedio E, Li K. A novel inorganic hollow fiber membrane reactor for catalytic dehydrogenation of propane. AIChE J 2009,55:2389-98.

[121] Wu JCS, Gerdes TE, Pszczolkowski JL, Bhave RR, Liu PKT, Martin ES. Dehydrogenation of ethylbenzene to styrene using commercial ceramic membranes as reactors. Sep Sci Technol 1990,25:1489-510.

[122] Kong C, Lu J, Yang J, Wang J. Catalytic dehydrogenation of ethylbenzene to styrene in a zeolite silicalite-1 membrane reactor. J Memb Sci 2007,306:29-35.

[123] She Y, Han J, Ma YH. Palladium membrane reactor for the dehydrogenation of ethylbenzene to styrene. Catal Today 2001,67:43-53.

[124] Yu C, Xu H. An efficient palladium membrane reactor to increase the yield of styrene in ethylbenzene dehydrogenation. Sep Purif Technol 2011,78:249-52.

[125] Tan X, Pang Z, Gu Z, Liu S. Catalytic perovskite hollow fibre membrane reactors for methane oxidative coupling. J Memb Sci 2007,302:109-14.

[126] Mazzotti M, Neri B, Gelosa D, Morbidelli M. Dynamics of a Chromatographic Reactor: Esterification Catalyzed by Acidic Resins. Industrial and Engineering Chemistry Research 1997, 36 (8), $3163-3172$.

[127] Kawase M, Yasunobu I, Araki T, Hashimoto K. The Simulated Moving-Bed Reactor for production of bisphenol A. Catalysis Today 1999, 48 (1 - 4), $199-209$.

[128] Kawase M, Suzuki TB, Inoue K, Yoshimoto K, Hashimoto K. Increased esterification conversion by application of the simulated moving-bed reactor. Chemical Engineering Science 1996, 51 (11), 2971 - 2976.

[129] Ray AK, Carr RW, Aris R. The simulated counter-current moving-bed chromatographic reactor: A novel reactor-separator. Chemical Engineering Science 1994, 49 (4), 469 - 480.

[130] Mazzzoti M, Kruglov A, Neri B, Gelosa D, Morbidelli M. A continuous chromatographic reactor: SMBR. Chemical Engineering Science 1996, 51 (10), 1827 - 1836. 
[131] Zhang Z, Hidajat K, Ray AK. Application of simulated counter-current moving-bed chromatographic reactor for MTBE synthesis. Industrial and Engineering Chemistry Research 2001, 40 (23), 5305 - 5316.

[132] Yu W, Hidajat K, Ray AK. Modelling, simulation, and experimental study of a simulated moving-bed reactor for the synthesis of methyl acetate ester. Industrial and Engineering Chemistry Research 2003, 42 (96), 6743 - 6754.

[133] Yu W, Hidajat K, Ray AK. Determination of adsorption and kinetic parameters for methyl acetate esterification and hydrolysis reaction catalyzed by amberlyst- 15 . Applied Catalysis A General, 2004, 260 (2), 191 - 205.

[134] Gelosa D, Ramaioli M, Valente G. Chromatographic reactors: Esterification of glycerol with acetic acid using acidic polymeric resins. Industrial and Engineering Chemistry Research 2003, 42 (25), 6536 - 6544.

[135] Gelosa D, Sliepcevich A., Morbidelli M. Chromatographic reactors with reactive desorbents. Industrial and Engineering Chemistry Research 2006, 45 (11), 3922 - 3925.

[136] Strohlein G, Assuncao Y, Dube N, Bardow A, Mazzotti M, Morbidelli M. Esterification of acrylic acid with methanol by reactive chromatography: Experiments and simulations. Chemical Engineering Science 2006, 61 (16), 5296 - 5306.

[137] Gyani V C, Mahajani SM. Reactive chromatography for the synthesis of 2-ethylhexyl acetate. Separation Science and Technology 2008, 43 (9-10), 2245-2268.

[138] Reddy B, Mahajani S. Feasibility of reactive chromatography for the synthesis of $n$-propyl acetate. Industrial and Engineering Chemistry Research 2014, 53 (4), 1395 - 1403.

[139] Falk T, Seidal-Morgenstern A. Comparison between a fixed-bed reactor and a chromatographic reactor. Chemical Engineering Science 1999, 54 (10), 1479 - 1485.

[140] Vu TD, Seidal-Morgenstern A, Gruner S, Kienle A. Analysis of ester hydrolysis reactions in a chromatographic reactor using equilibrium theory and a rate model. Industrial and Engineering Chemistry Research 2005, 44 (25), 9565 - 9574.

[141] Rangsunvigit P, Kulprathipanja S. Phenol hydroxylation with TS-1 in a chromatographic reactor. Separation Science and Technology 2004, 39 (14), 3301 - 3315.

[142] Juza M, Mazzotti M, Morbidelli M. Simulated moving-bed chromatography and its application to chirotechnology. Trends in Biotechnology 2000, 18 (3), 108 - 118.

[143] Gyani VC (Supervisor - Mahajani, SM). Reactive chromatography. PhD Thesis, Indian Institute of Technology, Mumbai, India, 2010. 
[144] Patel D, Saha B, Wakeman R. Optimisation of $n$-hexyl acetate synthesis in a chromatographic reactor. Journal of Ion Exchange 2010, 21 (4), 388 - 391.

[145] Patel D (Supervisor - Saha B). Synthesis of $n$-hexyl acetate in batch and chromatographic reactors. PhD Thesis, Loughborough University, UK, 2011.

[146a] Patel D, Saha B. Esterification of acetic acid with $n$-hexanol in batch and continuous chromatographic reactors using a gelular ion exchange resin as a catalyst. Industrial and Engineering Chemistry Research 2012a, 51 (37), 11965-11974.

[146b] Patel D, Saha B. Synthesis of n-hexyl acetate in batch and continuous chromatographic reactors using a dual property based gelular ion exchange resin catalyst. IEX $2012-$ Developments and Applications of Ion Exchange, Cambridge, UK, 2012b, 73-74 [CDROM].

[147] Broughton DB, Gerhold CG. Continuous sorption process employing fixed-bed of sorbent and moving inlets and outlets. US2985589 (Patent) 1961.

[148] Shieh MT, Barker PE. Saccharification of modified starch to maltose in a semi-continuous counter-current chromatographic reactor-separator (SCCR-S). Journal of Chemical Technology and Biotechnology 1995, 63, 125 - 134.

[149] Lode F, Francesconi G, Mazzoti M, Morbidelli M. Synthesis of methyl acetate in simulated moving-bed reactor: Experiment and modelling. AIChE Journal 2003, 49 (6), $1516-1524$.

[150] Den Hollander J L, Stribos BI, Van Buel MJ, Luyben K, Ch AM., Van Der Wielen LAM. Centrifugal partition chromatographic reaction for the production of chiral amino acids. Journal of Chromatography B 1998, 711 (1 - 2), 223 - 235.

[151] Den Hollander JL, Wong YW, Luyben K, Ch AM, Van Der Wielen LAM. Non-separating effects in a centrifugal partition chromatographic reactor for the enzymatic production of 1-amino acids. Chemical Engineering Science 1999, 54 (15 - 16), 3207 - 3215.

[152] Howard AJ, Carta G, Byers C H. Separation of sugars by continuous annular chromatography. Industrial and Engineering Chemistry Research 1988, 27, 1873 - 1882.

[153] Lode F, Houmard C, Migliorini C, Mazzoti M, Morbidelli M. Continuous reactive chromatography. Chemical Engineering Science 2001, 56 (2), 269 - 291.

[154] Agar DW, Ruppel W. Extended reactor concept for dynamic denox design. Chemical Engineering Science 1988, 43 (8), 2073 - 2078.

[155] Jeong YO, Luss D. Pollutant destruction in a reverse flow chromatographic reactor. Chemical Engineering Science 2003, 58 (7), 1095 - 1102. 
[156] Viecco GA, Caram HS. Analysis of the reverse flow chromatographic reactor. AIChE Journal 2004, 50 (9), 2266 - 2275.

[157] Viecco GA, Caram H S. Use of a reverse flow chromatographic reactor to enhance productivity in consecutive reaction systems. Industrial and Engineering Chemistry Research 2005, 44, 3396 - 3401.

[158] Mai PT, Vu TD, Mai KX, Seidal-Morgenstern A. Analysis of heterogeneously catalyzed ester hydrolysis performed in a chromatographic reactor and in a reaction calorimeter. Industrial and Engineering Chemistry Research 2004, 43 (16), 4691 - 4702.

[159] Vu TD, Seidal-Morgenstern A. Quantifying temperature and flow rate effects on the performance of a fixed-bed chromatographic reactor. Journal of Chromatography A 2011, $1218,8097-8109$.

[160] Falk T, Seidal-Morgenstern A. Analysis of a discontinuously operated chromatographic reactor. Chemical Engineering Science 2002, 57 (9), 1599 - 1606.

[161] Zafer I, Barker PE. An experimental and computational study of a biochemical polymerisation reaction in a chromatographic reactor separator. Chemical Engineering Science 1988, 43 (9), 2369 - 2375.

[162] Deshmukh KS, Gyani VC, Mahajani SM. Esterification of butyl cellosolve with acetic acid using ion exchange resin in fixed bed chromatographic reactors. International Journal of Chemical Reactor Engineering 2009, 7, Article A2.

[163] Sainio T, Zhang L, Seidel-Morgenstern A. Adiabatic operation of chromatographic fixedbed reactors. Chemical Engineering Journal 2011, 168, 861 - 871.

[164] Pereira CSM, Zabka M., Silva VMTM, Rodrigues AE. A novel process for the ethyl lactate synthesis in a simulated moving bed reactor (SMBR). Chemical Engineering Science 2009, 64, $3301-3310$.

[165] Fish BB, Carr RW. An experimental study of the counter-current moving-bed chromatographic reactor. Chemical Engineering Science 1989, 44 (9), 1773 - 1783.

[166] Ray AK, Carr RW, Aris R. The simulated counter-current moving-bed chromatographic reactor: A novel reactor-separator. Chemical Engineering Science 1994, 49 (4), 469 - 480.

[167] Meurer M, Altenhoner U, Strube J, Unitied A, Schmidt-Traub H. Dynamic simulation of a simulated moving-bed chromatographic reactor for the inversion of sucrose. Starch-Starke 1996, 48 (11-12), $452-457$.

[168] Kawase M, Pilgrim A, Araki T, Hashimoto K. Lactosucrose production using simulated moving-bed reactor. Chemical Engineering Science 2001, 56 (2), 453 - 458. 
[169] Tonkovich ALY, Carr RW. A simulated counter-current moving-bed chromatographic reactor for the oxidative coupling of methane - experimental results. Chemical Engineering Science 1994, 49 (24A), 4647 - 4656.

[170] Hoshimoto K, Adachi S, Nougima H, Ueda Y. A new process combining adsorption and enzyme reaction for producing higher-fructose syrup. Biotechnology and Bioengineering 1983, 25 (10), $2371-2393$.

[171] Minceva M, Gomes PS, Meshko V, Rodrigues A E. Simulated moving-bed reactor for isomerisation and separation of $p$-xylene. Chemical Engineering Journal 2008, 140 (1 3), $305-323$.

[172] Pereira CSM, Rodriques AE. Process intensification: New technologies (SMBR and PermSMBR) for the synthesis of acetals. Catalysis Today 2013, $218-219,148-152$.

[173] Silva VMTM, Rodrigues AE. Dynamics of a fixed bed adsorptive reactor for synthesis of diethylacetal. AIChE Journal 2002, 48 (3), 625 - 634.

[174] Silva VMTM, Rodrigues AE. Novel process for diethylacetal synthesis. AIChE Journal 2005, 51 (10), $2752-2768$.

[175] Pereira CSM, Sa Gomes P, Gandi GK, Silva VMTM., Rodrigues AE. Multi-functional reactor for the synthesis of dimethylacetal. Industrial and Engineering Chemistry Research 2008, 47 (10), $3515-3524$. 